\title{
16. LOWER TO MIDDLE EOCENE BENTHIC FORAMINIFERAL BIOFACIES AND LITHOSTRATIGRAPHIC UNITS AND THEIR RELATIONSHIP TO SEQUENCES, NEW JERSEY COASTAL PLAIN
}

\author{
James V. Browning, ${ }^{2}$ Kenneth G. Miller, ${ }^{2,3}$ and Richard K. Olsson ${ }^{2}$
}

\begin{abstract}
We use benthic foraminifers to evaluate water-depth changes within and between eight lower to middle Eocene sequences and examine the relationship between these sequences and previously recognized lithostratigraphic units. Integrated sequence and magnetobiostratigraphic studies presented elsewhere in this volume are used to recognize and correlate these sequences in the New Jersey Coastal Plain (Island Beach, Atlantic City, Allaire, and ACGS\#4 boreholes). Based on drilling at Allaire State Park, adjacent to the outcropping stratotypes, we correlate the Farmingdale and Deal Members of the Manasquan Formation to Sequences E1-lower E2 (lower lower Eocene) and upper E2-E4 (upper lower Eocene), respectively. We tentatively correlate the Squankum Member of the Shark River Formation to Sequence E5 (lowermost middle Eocene). The lower Shark River Formation correlates to Sequences E6 and E7 (lower middle Eocene), the upper Shark River Formation to Sequence E8 (upper middle Eocene), and the Toms River Member of the Shark River Formation to Sequence E9 (?upper Eocene).

Nine benthic foraminiferal biofacies are distinguished, and paleodepths for each are estimated using a paleoslope modeling technique. Water depths of $\sim 130 \mathrm{~m}$ existed in the boreholes examined throughout most of the early to middle Eocene, with maximum water depths of $185 \pm 15 \mathrm{~m}$ in the early Eocene. Shallower water depths $(50 \pm 10 \mathrm{~m}$ at Allaire to $75 \pm 15 \mathrm{~m}$ at Atlantic City) occurred in the middle Eocene. The timing and magnitude of water-depth changes in New Jersey Eocene sequences are similar to the eustatic changes inferred by Exxon. The coastal plain was not subaerially exposed during this time interval, and it is unknown what mechanism formed the unconformities found on the shelf at this time.
\end{abstract}

\section{INTRODUCTION}

Sequence stratigraphy provides an objective means to subdivide the stratigraphic record into genetically related successions (e.g., Christie-Blick and Driscoll, 1995). The primary control on passive margin sequence development is controversial, involving the interplay of tectonics, eustasy, and sediment supply (Miller, Chapter 1, this volume). Haq et al. (1987) evaluated both the timing and magnitude of Cenozoic sea-level change, assuming that sequence-boundary formation was controlled by eustasy. Their conclusions are controversial, in part, because the data on which they based their sea-level history are largely proprietary. In addition, the sea-level changes proposed by Haq et al. (1987) for the lower to middle Eocene are so large (e.g., >100 $\mathrm{m}$ at the early/middle Eocene boundary) and rapid that they are difficult to explain by mechanisms other than ice-volume change. This poses a problem because much of the Eocene is believed to have been ice free (see summary in Browning et al., 1996; Chapter 17 , this volume).

Utilizing materials from recently drilled boreholes at Island Beach, Mays Landing (ACGS\#4), Atlantic City, and Allaire State Park (Fig. 1), Browning et al. (1996; Chapter 17, this volume) identified and dated lower to middle Eocene Sequences E1 through E8 in the New Jersey Coastal Plain (Fig. 2) by integrating lithologic and well-log evidence for stratal discontinuities with biostratigraphic and magnetostratigraphic evidence for hiatuses. Benthic foraminiferal biofacies changes and evidence from benthic foraminifers of rapid deepening across stratal surfaces also helped supplement lithologic and well-log criteria used to delineate these lower to middle Eocene sequence boundaries (Browning et al., Chapter 17, this volume).

${ }^{1}$ Miller, K.G., and Snyder, S.W. (Eds.), 1997. Proc. ODP, Sci. Results, 150X: College Station, TX (Ocean Drilling Program).

${ }^{2}$ Department of Geological Sciences, Rutgers University, Piscataway, NJ 08855 , U.S.A. jvb@rci.rutgers.edu

${ }^{3}$ Lamont-Doherty Earth Observatory of Columbia University, Palisades, NY 10964, U.S.A.
In addition to aiding in the delineation of sequence boundaries, benthic foraminiferal changes can be used to assess water-depth changes within and between sequences and to delineate facies variations within sequences (systems tracts of Posamentier et al., 1988). Benthic foraminifers are widely used for paleobathymetric estimates (e.g., van Morkhoven et al., 1986). Benthic organisms are environmentally sensitive and generally inhabit relatively narrow ranges of environmental conditions. Although depth is not of itself an important limiting factor (see summary in Douglas, 1979), species living on the shelf are affected by a number of environmental parameters that tend to vary proportionately with depth. These include substrate type, light, salinity, hydrostatic pressure, and temperature (Douglas, 1979). Thus, interpretations of paleodepth from benthic organisms rely on second-order correlations, which may vary spatially and temporally.

Early paleodepth studies applied the depth ranges of modern taxa directly to the past, assuming the depth ranges of modern and related fossil taxa were similar (see summary in Douglas, 1979). This can lead to incorrect paleodepth interpretations if individual taxa have changed their habitats and migrated to new depths through time. In addition, most Eocene benthic foraminiferal species are extinct, requiring application of the modern depth range of the genus instead of the species. Genera as a whole have much wider environmental tolerances and, therefore, depth ranges than any one of the constituent species. A second approach, pioneered by Bandy (1953a, 1953b), assumed that taxa with similar morphologies had similar trophic needs and inhabited similar environments. This approach has been rarely used on the shelf to study the depths of assemblages.

Rather than rely on the occurrence of individual taxa, other studies have used assemblages of benthic foraminifers to infer depth (Douglas, 1979). Within a sequence, changes in benthic foraminiferal assemblages should obey Walther's Law of Facies. During a transgression, the populations living farther out on the shelf should be placed stratigraphically above those living nearer to shore. Olsson and Nyong (1984) and Olsson et al. (1987) used a paleoslope modeling technique to reconstruct benthic foraminiferal biofacies onto a dip profile applying Walther's Law (assuming biofacies found in 


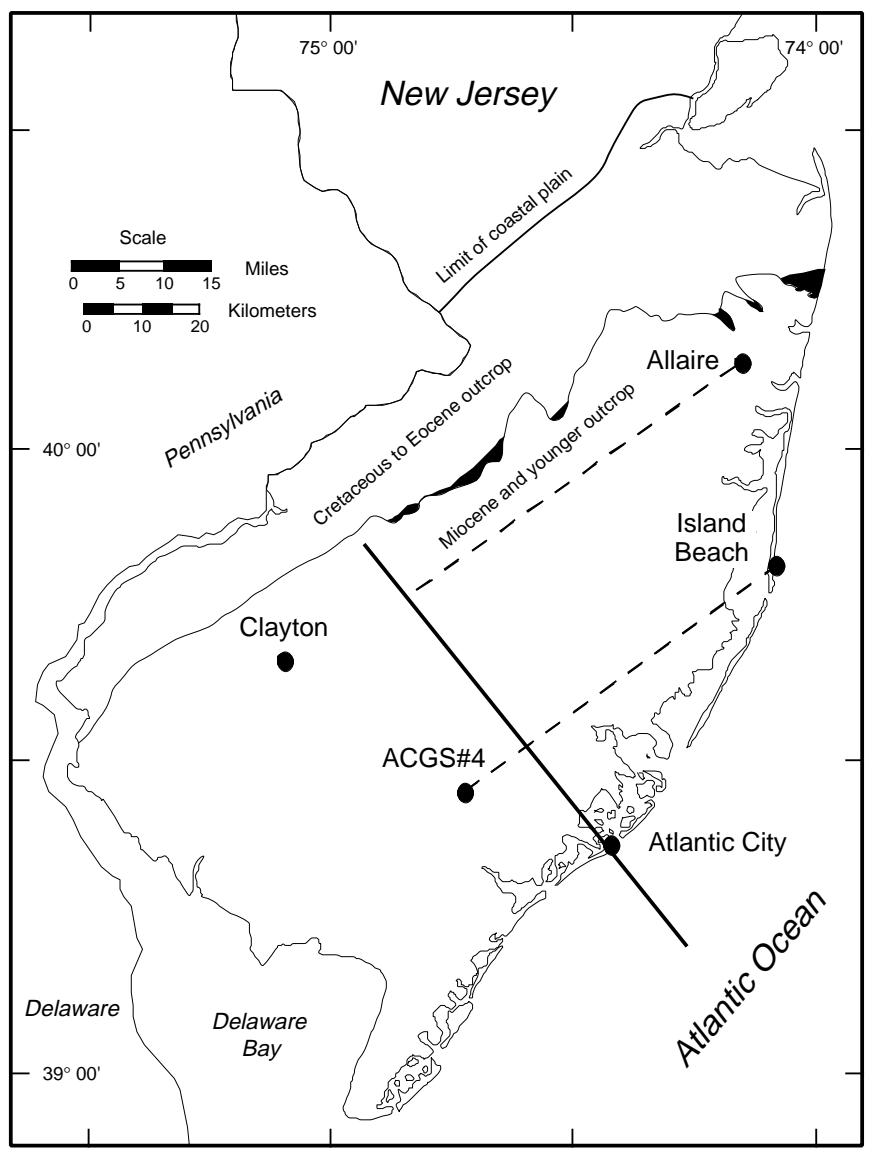

Figure 1. Location map showing boreholes on the New Jersey Coastal Plain discussed in the text. Dark pattern indicates location of Eocene outcrop (after Enright, 1969a). Outcrop belts are shown only for New Jersey. A dip profile is drawn through Atlantic City and projections from Allaire, ACGS\#4, and Island Beach are shown.

downdip sections at a given time are in deeper water than those in updip sections). The paleoslope modeling technique identifies biofacies using standard methods (cluster or factor analysis), dates the faunal successions, and projects them onto a dip section assuming a given paleogradient. Setting limits for biofacies depths is difficult when near-shore facies are not recovered. When near-shore facies are not found, then it is necessary to estimate the depth of the shallowest biofacies found. Implicit in paleoslope modeling is the assumption that the slope of the shelf is approximately the same as it is today (1:1000). Although this may not be true, altering the gradient only alters the absolute depth estimates, not the relative water-depth estimates. The strength of this method is its ability to resolve relative water-depth changes over time.

Olsson and Wise (1987b) applied this paleoslope approach to benthic foraminifers in the greater than $63-\mu \mathrm{m}$-size fraction from samples found in the lower to middle Eocene section of New Jersey. Using split-spoon samples from wells on the New Jersey Coastal Plain, they identified six sequences and five biofacies and estimated paleodepths for these biofacies. They found that maximum water depths occurred in the early Eocene, a shallowing of approximately $90 \mathrm{~m}$ took place at the early/middle Eocene boundary, and shallowing occurred in the middle Eocene. Their study provided a good overview of lower to middle Eocene sequences. However, they did not sample upper Eocene strata, nor did their discontinuous samples provide a comprehensive view of Eocene benthic foraminiferal biofacies distribution.
The purpose of this paper is to reconstruct the benthic foraminiferal biofacies in the $>150-\mu \mathrm{m}$-size fraction from lower to middle Eocene strata on the New Jersey Coastal Plain and use them to reconstruct water-depth changes throughout this interval. The benthic foraminifers from the New Jersey Coastal Plain are generally well preserved and very abundant. We also examine the $<150-\mu \mathrm{m}$-size fraction (i.e., the same size fraction examined by Olsson and Wise [1987b]) to evaluate the differences between the two size fractions. The biofacies and inferred paleodepths are placed into a sequence stratigraphic framework, integrating the results with biostratigraphy, magnetostratigraphy, and other dating techniques (see Browning et al., Chapter 17, this volume). We incorporate data from several new boreholes that recovered $937 \mathrm{ft}(285.6 \mathrm{~m})$ of continuously cored lower to middle Eocene sediments. This allows a more complete reconstruction of Eocene biofacies than previously possible.

\section{METHODS \\ Sequences and Lithostratigraphy}

Data were obtained from four continuously cored New Jersey Coastal Plain boreholes. Two of these were drilled as part of Ocean Drilling Program (ODP) Leg 150X at Island Beach (Fig. 1; Miller et al., 1994b) and Atlantic City (Miller et al., 1994a), whereas the other two were drilled as a cooperative program between the U.S. Geological Survey and the New Jersey Geological Survey at Mays Landing, NJ (ACGS\#4; drilled in 1984; Owens et al., 1988) and Allaire State Park (ASP; drilled in March, 1988; Sugarman et al., 1991).

Preliminary lithologic descriptions (sedimentary textures, structures, and colors), identification of lithostratigraphic units, biostratigraphic dating, and documentation of stratal surfaces (including sequence boundaries and flooding surfaces) were provided for Island Beach and Atlantic City by Leg 150X studies (Miller et al., 1994a, 1994b). Preliminary lithostratigraphy and sequence stratigraphy for the ACGS\#4 borehole is provided by Owens et al. (1988) and Miller et al. (1990). Lithostratigraphic and sequence stratigraphic interpretations for the ASP borehole and additional analysis of the other three boreholes are provided by Browning (1996), Browning et al. (Chapter 17, this volume), and this study. Samples from Island Beach were analyzed at Woods Hole Oceanographic Institution for percent calcium carbonate by weight using the Automated Carbonate System (Ostermann, et al., 1990) with a precision of $0.8 \%-1.0 \%$.

Browning et al. (Chapter 17, this volume) determined unconformities (sequence boundaries) in the boreholes and the duration of their associated hiatuses by integrating studies of lithostratigraphy, planktonic foraminiferal and calcareous nannofossil biostratigraphy, magnetostratigraphy, and benthic foraminiferal biofacies studies. Disconformities in the four boreholes were identified on the basis of physical and geophysical criteria (including irregular contacts, reworking, bioturbation, major facies changes, and gamma-ray peaks). Paraconformities were inferred from biostratigraphic and magnetochronologic breaks. Studies of benthic foraminiferal biofacies helped to confirm and identify disconformities and paraconformities. Recognition of these surfaces allowed identification of sequences.

Age-depth diagrams of the Island Beach and ACGS\#4 boreholes were used to integrate ages of significant bioevents with magnetostratigraphy (Browning et al., Chapter 17, this volume). The two boreholes have comparable magnetobiostratigraphic resolution, although the lower lower Eocene was not cored at ACGS\#4. The Atlantic City borehole recovered little of the middle Eocene and its age is constrained only by biostratigraphy. The updip ASP borehole is difficult to date accurately because the section is more condensed, magnetostratigraphy is difficult in the sandier sediments, and biostratigraphic markers are rarer. Correlation of ASP to Island Beach was accomplished using available biostratigraphy and magnetostratigraphy and benthic biofacies. Because the chronology of the 


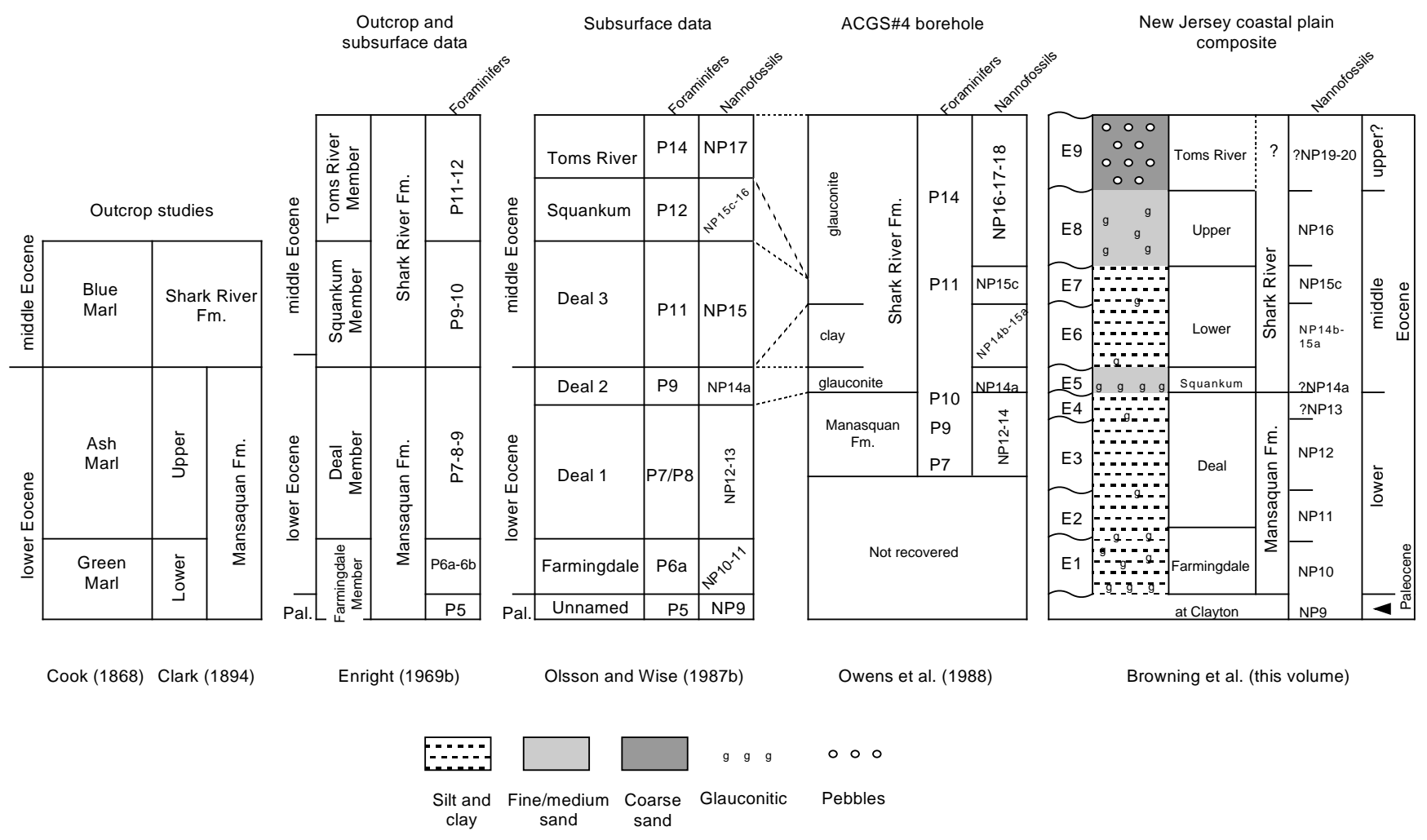

Figure 2. Comparison of stratigraphic nomenclature for the Eocene sediments from the New Jersey Coastal Plain.

New Jersey lower to middle Eocene sections can be directly tied to the geomagnetic polarity time scale, it typically has a resolution of 0.5 m.y. or better. The time scale of Berggren et al. (1995) is used throughout.

An attempt was also made to interpret the systems tracts of Eocene sequences in these boreholes. It is often difficult to differentiate systems tracts and to identify maximum flooding surfaces (MFSs) in these lithologically homogenous sediments. In the New Jersey Coastal Plain, lowstand systems tracts are generally excluded and it is only the transgressive systems tracts (TST) and highstand systems tracts (HST) that are found. A typical New Jersey Coastal Plain sequence has glauconite at the base, interpreted as the TST, overlain by early HST clays and silts with late HST sands at the top (Sugarman et al., 1993). In the Eocene, the New Jersey onshore sediments are from relatively deep water, and much of the TSTs and early HSTs are condensed sections. Benthic foraminiferal studies are used to recognize the deepest water depths of a sequence associated with MFSs that separate TSTs from HSTs. In addition, HSTs can be recognized as generally shallowing-upward successions.

\section{Benthic Foraminiferal Studies}

The sampling interval for benthic foraminiferal studies was usually $5 \mathrm{ft}(1.5 \mathrm{~m})$ in the ASP and ACGS\#4 boreholes, $10 \mathrm{ft}(3 \mathrm{~m})$ in the Island Beach and Atlantic City boreholes, and was as close as $3 \mathrm{ft}$ in stratigraphically sensitive intervals. Samples of approximately 20 $\mathrm{cm}^{3}$ were disaggregated in a sodium metaphosphate solution. Some samples were soaked first in 3\% hydrogen peroxide to remove organic matter and to speed the disaggregation process. Hydrogen peroxide treatment was discontinued because some samples contained sulfides and it was feared that a reaction between these sulfides and the hydrogen peroxide might create a weak acidic solution that could etch the fossils and make identification more difficult. Samples that did not respond to the sodium metaphosphate treatment were boiled in sodium chloride, and a few samples from the ACGS\#4 borehole were boiled with Quaternary O to disaggregate them. The materials were washed through a $63-\mu \mathrm{m}$ mesh to remove the clay and silt. The dried samples were sieved to obtain the $>150-\mu \mathrm{m}$ fraction. The samples were split using a microsplitter to obtain $\sim 300$ specimens for quantitative analysis. All specimens in a split were picked. The 63- to 150$\mu \mathrm{m}$ fraction was saved for qualitative analysis.

Benthic foraminifers were identified to the species level using the taxonomy of Tjalsma and Lohmann (1983), Jones (1983), Bandy (1949), Enright (1969b) and Charletta (1980). The data set was converted to percentages and Q-mode factor analysis was used to compare variation among the samples. The factors obtained were rotated using Varimax Factor analysis using Systat 5.2.1 run on a Macintosh microcomputer. In general, factor loadings above 0.5 were considered significant. Qualitative analysis was conducted on the 63- to $150-\mu \mathrm{m}$ fraction so that the depth estimates calculated by Olsson and Wise (1987b) could be used and to compare differences that may exist between the two data sets. A visual estimate of species abundances in the 63- to $150-\mu \mathrm{m}$-size fraction was conducted and the paleobathymetric biofacies of Olsson and Wise (1987b) were identified.

For this paper the bathymetric zonation of van Morkhoven et al. (1986) is used: $0-30 \mathrm{~m}$ is inner neritic, $30-100 \mathrm{~m}$ is middle neritic, $100-200 \mathrm{~m}$ is outer neritic, and $200-600 \mathrm{~m}$ is upper bathyal. The paleoslope modeling technique is discussed below together with the biofacies.

\section{LITHOSTRATIGRAPHY AND SEQUENCE STRATIGRAPHY}

Previous Work

Conrad (1865) first recognized Eocene sediments in New Jersey and gave the name Shark River Marl to small outcrops near Asbury Park, NJ. Cook (1868) subdivided the Eocene, which he termed the upper marl bed, into three units: the Green Marl at the base, the Ash Marl, and the Blue Marl (Fig. 2). The Manasquan Formation was for- 
mally defined by Clark (1894), who included the Green Marl and the Ash Marl in the Manasquan Formation, and assigned the Blue Marl to the Shark River Formation.

The first detailed work on Eocene sediments was by Enright (1969a, 1969b). Using samples obtained by cable tool from a well drilled near Brick Township, NJ, he correlated the Manasquan Formation to the early Eocene and the Shark River Formation to the middle Eocene using the planktonic foraminiferal zones of Bolli (1957a, 1957b). He also divided the Manasquan Formation into two members: the Farmingdale Member, a medium to coarse clayey, quartzose glauconite sand, below, and the Deal Member, a sandy clay, above (Fig. 2). The contact between the two members is gradational and is defined as the point downsection where coarse glauconite sand grains appear in more than trace amounts. The Farmingdale Member is 40 ft thick $(12.2 \mathrm{~m})$ in outcrop. The contact with the Vincentown Formation, wherever observed, is disconformable. The contact is sharp, with an abrupt change from the slightly glauconitic quartz sand of the Vincentown Formation below to glauconite sands above, with frequent rip-up clasts of the Vincentown Formation reworked into the Farmingdale Member. Enright (1969b) also divided the Shark River Formation into the Squankum Member, an argillaceous, glauconite sand, and the Toms River Member, a fine to medium quartz sand found only in the subsurface (Fig. 2). Enright (1969b) concluded that both the Farmingdale and Squankum Members thin downdip and are replaced by the Deal Member lithology, making distinction between the two formations impossible.

The sequence stratigraphy of the Eocene units was first considered by Olsson and Wise (1987a, 1987b). Using discontinuously sampled wells and boreholes, they divided the lower and middle Eocene into six sequences. A sequence representing an unnamed formation was recognized in the uppermost Paleocene (planktonic foraminiferal Zone P5). Previously, this unit had been described as part of the Vincentown Formation, but Olsson and Wise (1987a) found major unconformities separating it from both the Vincentown Formation below and the Manasquan Formation above. When describing Eocene sequences they followed the stratigraphic terminology of Enright (1969b) but they revised the ages for members from those given by Enright. Glauconitic facies from the lowermost Eocene (Zone P6b) were assigned to the Farmingdale Member. Sediments containing Zones P8 to P11 were assigned to the Deal Member. Contrary to Enright (1969b), who assigned the Squankum Member to Zones P9 to P10, Olsson and Wise (1987b) assigned the glauconitic and siliciclastic materials from Zone P12 to the Squankum Member. The more coarsely siliciclastic materials above were assigned to the Toms River Member (Zone P14?).

The ACGS\#4 borehole was the first continuously cored borehole on the New Jersey Coastal Plain to recover a thick Eocene section (Owens et al., 1988), and it provided material for study of the facies and environments of deposition, although much of the lower Eocene was not penetrated (only $40 \mathrm{ft}$ [12.2 m] was recovered). Owens et al. (1988) used the formational terminology of Enright (1969b) but did not use Enright's members (Fig. 2). Their work was primarily sedimentological in scope and did not fully address the sequence stratigraphy of the units identified. The Manasquan Formation is the oldest unit penetrated, and it is described as crudely bedded to finely laminated, pale olive, clayey silt (i.e., the "ash-colored marls" of Cook [1868]) with common burrows and fine glauconite sand. The Manasquan Formation spans Zones P7 to P10 (NP12-NP14; Poore and Bybell, 1988). The contact with the overlying Shark River Formation is unconformable. At its base, the Shark River Formation is light colored, yellowish green, clayey silt and silty very fine sand with glauconite, and it is assigned to lower middle Eocene Zones NP14a and NP15a (Owens et al., 1988; Poore and Bybell, 1988). The base of the upper half contains clayey silt and sand with abundant glauconite. Medium to coarse glauconite grains become increasingly abundant upsection and are most common in the upper $35 \mathrm{ft}$ (10.7 m). This upper unit corresponds to Olsson and Wise's (1987b) Deal 3 and Toms River sequences. Upper Eocene material (Zones NP18-NP21; Poore and Bybell, 1988) was informally called the ACGS Alpha unit because no other material of this age had previously been reported from New Jersey north of Cape May (see Browning et al., Chapter 18, this volume, for discussion of New Jersey upper Eocene sediments).

By integrating published studies of foraminiferal and calcareous nannoplankton biostratigraphy (Poore and Bybell, 1988), and lithostratigraphy (Owens et al., 1988) from the ACGS\#4 borehole, with studies of magnetostratigraphy, and Sr-isotopic stratigraphy, Miller et al. (1990) delineated five Eocene sequences from the ACGS\#4 borehole (Fig. 2) and applied the formational nomenclature of Olsson and Wise (1987b). All of the uniform light colored marls older than calcareous nannoplankton Zone NP16 were included in the Deal Member of the Manasquan Formation. Their assignment to the Deal Member differs from Owens et al. (1988), who used Enright's (1969b) criteria (the lowest glauconite sand bed) to recognize the base of the Shark River Formation. The Deal Member at the ACGS\#4 borehole consists of three sequences, one older than Magnetochron $\mathrm{C} 22$, a second deposited during $\mathrm{C} 22$, and a third younger than $\mathrm{C} 22$ to the top of the member. A fourth sequence (containing mixed biostratigraphic indicators but assigned to Zones NP17-NP18) was placed in the Shark River Formation. The fifth sequence consisted of the upper Eocene ACGS Alpha unit (NP19/20-NP21) and the lowermost Oligocene Mays Landing unit (NP21). Christensen et al. (1995) used benthic foraminiferal biofacies to refine the work of Miller et al. (1990). They confirmed the existence of a sequence near the lower/ middle Eocene boundary that correlates to Magnetochron C22, and distinguished sequence boundaries within the stratigraphically mixed unit, and between the upper Eocene ACGS alpha unit and the lower Oligocene Mays Landing unit.

The Paleocene/Eocene boundary was reported by Gibson et al. (1993) in an updip borehole drilled at Clayton, NJ (Fig. 1). The unit containing the boundary contains similar benthic foraminiferal biofacies and is lithologically similar to the uppermost Paleocene sequence described by Olsson and Wise (1987b). Based on calcareous nannoplankton biostratigraphy, Gibson et al. (1993) concluded that this unit spanned the Paleocene/Eocene boundary and contained a continuous record of sedimentation across the Zone NP9/NP10 boundary.

\section{This Study}

The evolution/history of the New Jersey Coastal Plain Eocene stratigraphic nomenclature from outcrop (Cook, 1868; Clark, 1894) through Enright's (1969b) outcrop and subsurface studies, through modern subsurface studies (Olsson and Wise, 1987a; Owens et al., 1988; Miller et al., 1990) illustrates an increasing degree of subdivision and complexity culminating in the recognition by Browning et al. (Chapter 17, this volume) of eight lower to middle Eocene sequences (Fig. 2). Although Enright's (1969b) lithostratigraphic units can be applied to lower Eocene strata, his terminology is difficult to follow for most of the middle Eocene sediments. Contrary to Enright (1969b), the middle Eocene in the subsurface sections examined here does not consist solely of a glauconite sand (Squankum Member) overlain by a quartz sand (Toms River Member).

Correlation between outcrops and downdip boreholes is difficult because the outcrops generally lack calcareous fossils. To circumvent this problem, the ASP borehole was drilled adjacent to the type section of the Manasquan Formation to help understand the age relationships of the New Jersey lower to middle Eocene section (Fig. 3). Because of its proximity to the outcrops and the similarity of lithofacies, this site provides a means of correlating poorly fossiliferous outcrops with their downdip equivalents.

The Paleocene/Eocene boundary is missing from the boreholes studied here. In outcrop and in these boreholes, basal sediments of the Manasquan Formation that contain abundant glauconite sand are defined as the Farmingdale Member (Fig. 2). At outcrop, this unit is barren of calcareous fossils because of dissolution. The Farmingdale Member is represented at the base of the Island Beach borehole (Fig. 
3). A similar facies is also found in the TST at the base of the E2 sequence to $1018 \mathrm{ft}$ (310.3 m; see Browning et al. [Chapter 17, this volume]). Without detailed biostratigraphic data, the hiatus separating the two sequences would not be suspected (Browning et al., Chapter 17, this volume). Lithostratigraphically, these two units should be combined (i.e., the Farmingdale Member at Island Beach is equivalent to Sequences E1 and lower E2).

The basal Manasquan Formation sediments at the ASP borehole contain abundant glauconite sand assigned to Zone NP11 (Browning et al., Chapter 17, this volume) and are equivalent to Sequence E2 at Island Beach. Sequence E1 has not been definitely identified at the ASP borehole, although the lowermost $7 \mathrm{ft}(2.1 \mathrm{~m})$ is barren of calcareous fossils and may represent a separate sequence equivalent to Sequence E1. Thus, the Farmingdale Member at ASP (and by short correlation, the equivalent in outcrop) corresponds to the TST from Sequence E2 (Figs. 2, 3) and possibly the lowermost Eocene Sequence E1 (Zone NP10; Fig. 3).

The Deal Member at outcrop is also barren of calcareous fossils. At both the ASP and Island Beach boreholes, upper lower Eocene sediments are slightly sandy clays similar to those of the Deal Member at outcrop (Figs. 2, 3). These are correlated to Sequences E2, E3, and E4 and Zones NP11, NP12, and NP13, respectively.

The term Squankum Member has been used inconsistently and the definition of this unit requires clarification. Enright (1969b) differentiated at outcrop the Squankum Member of the Shark River Formation (a glauconite sand) from the Deal Member of the Manasquan Formation by the upsection appearance of coarse glauconite sand grains in more than trace amounts. He assigned the member to Zones P9 and P10 by lithostratigraphic correlation to the Brick Township well. He found that the Squankum Member ranges up to $40 \mathrm{ft}$ thick $(12.2 \mathrm{~m})$ at outcrop and that the contact with the underlying Deal Member is gradational. In both the ACGS\#4 and Island Beach boreholes, a surface occurs near the lower/middle Eocene boundary, above which the sediments are dominated by medium- to coarsegrained glauconite sand. This glauconite sand at ACGS\#4 was used by Owens et al. (1988) to separate the Shark River and Manasquan Formations. Poore and Bybell (1988) assigned this glauconite unit to Zone NP14a, which straddles the lower/middle Eocene boundary. The glauconite sand unit at Island Beach is of similar age (Miller et al., 1994b) and it marks the base of Sequence E5 of this study (Fig. 3 ). There is evidence that several thin sequences were deposited on the New Jersey Coastal Plain in a short interval spanning the early/ middle Eocene boundary (Browning et al., Chapter 17, this volume).

It is not clear if this Zone NP14a glauconite sand at Island Beach is equivalent to the Squankum Member of Enright (1969b) at outcrop (Fig. 3). A glauconite sand is found in the ASP borehole near the lower/middle Eocene boundary. Similar to the findings of Enright (1969b), the contact with the underlying Deal Member appears to be gradational, although core recovery is incomplete (a 3-ft section [1 m] of core was not recovered) and the contact might have been lost. Biostratigraphic dating of this unit at the ASP borehole, which is critical to resolving the age of nearby outcrops, is not possible (L.M. Bybell, pers. comm., 1993). In the ASP borehole (Fig. 3), marls overlying the glauconitic unit are assigned to Zone NP15c (L.M. Bybell, pers. comm., 1993) and the underlying glauconite sand appears to be part of the same sequence (Sequence E7). Basal Sequence E7 glauconites at Island Beach and ACGS\#4 are dominated by clay, with only a few percent fine glauconite and little or no medium to coarse glauconite.

The age and geographic distribution of the Squankum Member cannot be fully resolved at this time. The Squankum Member, where it is defined at outcrop, may be the basal glauconite for Sequence E7. If this is the case, the Squankum Member is not correlative with the lower/middle Eocene glauconites at Island Beach and ACGS\#4. However, it is equally plausible that a lower/middle Eocene (Zone NP14a) sequence at the ASP borehole was not identified because of poor recovery and bioturbation. If this is true, the Squankum Member is lowermost middle Eocene (Zone NP14a) and is the basal glaucon- ite of Sequence E5. Because of the consistent occurrence of a thick, coarse glauconite at the base of the Shark River Formation, it seems most likely that this unit is of the same age and is correlative at our study sites. We assigned it to Sequence E5. It is not possible at this time to test Enright's (1969b) contention that the Squankum Member thins downdip and is replaced by a Deal lithology. In all boreholes we studied, glauconitic sands overlie lower Eocene marls.

Sequences E6, E7, and E8 were not recognized in the outcrops or wells studied by Enright (1969b) and thus were not included in his stratigraphic framework of the Eocene (Fig. 3). Owens et al. (1988) retained the name Shark River for all middle Eocene strata, because no other name for middle Eocene strata had been proposed. Three separate lithologies are found in the middle Eocene. Sequences E5, E6, and E7 are marls, each having greater or lesser concentrations of glauconite sand at its base. These marls are lithologically similar to the marls in the Manasquan Formation, but do not contain abundant siliceous microfossils as are found in the Deal Member. We place these marls in the lower Shark River Formation (Fig. 2).

In all boreholes, these marls are overlain across a sharp surface by coarser materials containing quartz and glauconite sand equivalent to Sequence E8 (Zones NP16 and P12) of the Shark River Formation. This grades up to a medium to coarse quartz sand, which is equivalent to Enright's (1969b) Toms River Member. Olsson and Wise's (1987b) interpretation that the Zone P12 (NP16) sediments are equivalent to the Squankum Member is probably not correct. P.J. Sugarman (pers. comm., 1995) has found outcrops of this coarser grained unit on the Manasquan River stratigraphically above the Shark River Formation glauconite sand. This coarser grained unit seems to be a separate unit, which has been referred to as the upper Shark River Formation (Miller et al., 1994b).

The Toms River Member, equivalent to Sequence E9 (Fig. 2), is difficult to interpret. The Toms River Member is correlative to a widespread unit on the coastal plain, outer shelf, and continental slope (Poag and Aubry, 1995; Thein, 1987; Miller et al., 1991, 1994a) that contains a mixture of biostratigraphic indicators. Middle Eocene members of the planktonic foraminiferal genera Morozovella, Acarinina, and Truncorotaloides, which become extinct at the end of Biochron P14 (38.4 Ma), are mixed with calcareous nannoplankton indicative of upper Eocene Zones NP18 and NP19/20. The lower surface of this unit is sharp at Island Beach, where sand percentages abruptly increase to nearly $50 \%$. Whereas the stratigraphically mixed layer is widespread, the medium to coarse sand is restricted to the updip boreholes. At Atlantic City, the base of this unit is not clearly defined and the lithology is gradational with the upper Shark River unit below, although biostratigraphic mixing is noted. The coarse facies is not present at Atlantic City. The top of this unit consists of a black clay containing an abundant microfauna. Calcareous nannoplankton indicate that the black clay is upper Eocene (NP19/20), implying the reworking of abundant, diverse, and well-preserved middle Eocene planktonic foraminifers over an interval of $50 \mathrm{ft}$ at Island Beach. Such dramatic mixing is not generally observed in other units on the New Jersey Coastal Plain. The Toms River Member correlates biostratigraphically with the Exmore breccia, which fills the Chesapeake Bay impact crater (southeast Virginia; Poag et al., 1992). Poag et al. (1992) suggested that the impact caused giant tsunami waves which reworked sediments on the inner shelf and coastal plain. We attribute the biostratigraphic mixing found in the Toms River Member as the possible result of redeposition of shelf sand, silt, and clay caused by tsunami activity.

\section{BIOFACIES Factor Analysis}

Ninety-six samples were examined from the lower to middle Eocene and a total of 179 species were identified from approximately 32,000 specimens (see Browning [1996] for data file). Nine strati- 


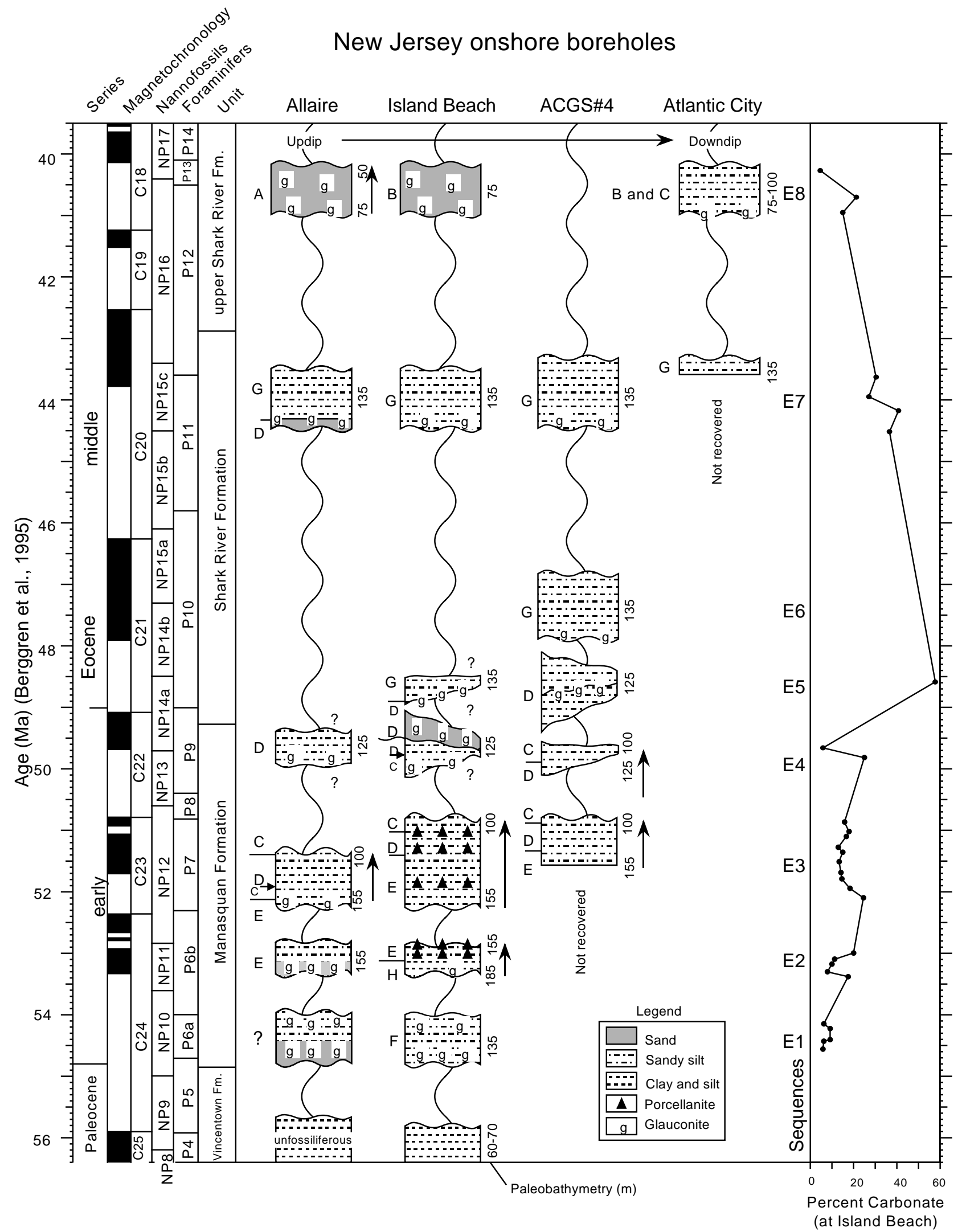

Figure 3. Distribution of sediments from the New Jersey Coastal Plain. Time is shown as a function of time calibrated to the time scale of Berggren et al. (1995). Wavy lines indicate unconformities. Diagonal unconformities are used to show the uncertainties in age. E1 to E8 indicate Eocene sequences. Letters A through $\mathrm{H}$ indicate benthic Biofacies A through $\mathrm{H}$ defined in text. Paleodepth estimate for the Vincentown Formation from Liu et al. (Chapter 19, this volume). Arrows indicate depth gradient within sequences. 
graphically interpretable factors, which explained $79.9 \%$ of the faunal variation, were rotated (Fig. 4; see Browning [1996] for factor analysis). The factors represent eight discrete groupings of individual species (Figs. 5-8). These biofacies have predictive value concerning the depositional environments of the sediments in which they are found and can be used to determine paleobathymetry. The biofacies and the factors that define them are discussed from shallowest (Biofacies A) to deepest (Biofacies $\mathrm{H}$ ).

\section{Biofacies A}

This biofacies is defined by Factor 5, which explains $4.8 \%$ of the faunal variation. It is dominated by Globobulimina ovata (score $=$ 6.2), Cibicidina praeconcentricus (score $=5.2$ ), and Gyroidinoides octocameratus (score $=4.5$; Figs. 6,8$)$. Other important members of the assemblage include Cibicidoides cocoaensis, Alabamina wilcoxensis, and Hanzawaia mauricensis. The fine fraction is dominated by Pararotalia inconspicua with common Epistominella minuta and Uvigerina elongata; this is equivalent to Olsson and Wise's (1987b) Biofacies 1 (estimated as $50 \pm 10 \mathrm{~m}$ ). It is found only in the ASP borehole in the upper Shark River Formation. Elements of this fauna are also found in the upper Shark River in the Atlantic City borehole, where it is associated with increased glauconite and siliciclastics. Globobulimina from the modern ocean is known from neritic to bathyal depths (Murray, 1991). The average percent planktonic foraminifers for samples belonging to this biofacies is $1.8 \%$.

\section{Biofacies B}

This biofacies is defined by Factor 7, which explains $4.4 \%$ of the faunal variation. It is dominated by Cibicidoides pippeni (score $=$ 10.3), with common Hanzawaia blanpiedi (score $=4.4$ ) and Alabamina wilcoxensis (score $=3.6$; Figs. 5, 6, and 8). It is found at the base of the upper Shark River Formation. It is equivalent to Olsson and Wise's (1987b) Biofacies 2 (estimated as $75 \pm 15 \mathrm{~m}$ ). The average percent planktonic foraminifers for samples belonging to this biofacies is $29 \%$.

\section{Biofacies $C$}

This biofacies is defined by Factor 6 which explains 5.5\% of the faunal variation. It is dominated by Cibicidoides pseudoungerianus (score =7.6), Anomalinoides acuta (score =6.2), and Cibicidoides cocoaensis (score $=5.5$; Figs. 5, 7, and 8). Other common taxa are Discorbis huneri and Lenticulina midwayensis. The fine fraction generally contains abundant Turrilina robertsi and Bulimina whitei and is equivalent to Olsson and Wise's (1987b) Biofacies 3 (estimated paleodepth of $100 \pm 10 \mathrm{~m}$ ). This biofacies is distinguished by the absence of other organisms such as $S$. claibornensis and $C$. aff. subspiratus. The average percent planktonic foraminifers for samples belonging to this biofacies is $72 \%$.

\section{Biofacies $D$}

This biofacies is defined by Factor 1, which explains $20.3 \%$ of the faunal variation and is dominated by Siphonina claibornensis (score $=12.2$; Figs. 5, 7, and 8). Its average occurrence in these samples is $23.5 \%$ and reaches $56 \%$ in some parts of the ASP borehole. In addition, Anomalinoides acuta (score $=4.3$ ) and Cibicidoides ungerianus (score $=1.2)$ are important components of the fauna. This biofacies is present in all of the boreholes at the top of the lower Eocene (Sequences E3 and E4). Siphonina in the modern ocean is known from both neritic and bathyal depths (van Morkhoven et al., 1986), but it was confined to neritic depths until the Oligocene (van Morkhoven et al., 1986). This species is characteristic of assemblages that Olsson and Wise (1987b) place in their Biofacies 4, which they estimated oc- curred in paleowater depths of $135 \pm 25 \mathrm{~m}$. The average percent planktonic foraminifers for samples belonging to this biofacies is $64 \%$.

\section{Biofacies $\boldsymbol{E}$}

This biofacies is defined by Factor 3, which explains $15.3 \%$ of the faunal variation. It is dominated by Cibicidoides aff. subspiratus (score $=10.7)$, with common Anomalinoides acuta $($ score $=4.0)$, Cibicidoides eocaena $($ score $=3.5)$, and Turrilina robertsi (score $=$ 2.2; Figs. 5, 7, and 8). This biofacies dominates the bulk of the Deal Member of the Manasquan Formation. It is typically found in finegrained sediments containing abundant radiolarians. A. acuta is similar to and may be synonymous with Cibicidoides micrus (note that A. acuta would be the senior synonym). This assemblage is generally found with $P$. subrotundata, indicating Olsson and Wise's (1987b) Biofacies 4 with an estimated paleodepth of $135 \pm 25 \mathrm{~m}$. The average percent planktonic foraminifers for samples belonging to this biofacies is $66 \%$.

\section{Biofacies $\boldsymbol{F}$}

This biofacies is defined by Factor 4, which explains $7.5 \%$ of the faunal variation. It is dominated by Cibicidoides cf. mimulus (score =7.4), Osangularia expansa (score = 6.7), and Anomalinoides acuta (score $=5.2$; Fig. 5). This biofacies is found only in the Island Beach borehole in Sequence E1. The sequence in which it was found typically contains glauconite ranging from $20 \%$ at the base to $5 \%$ higher in the section. The fine fraction is dominated by $P$. subrotundata and Tappanina selmensis, and Pulsiphonina prima are common. This would place it in Olsson and Wise's (1987b) Biofacies 4 (estimated depth of $135 \pm 25 \mathrm{~m}$ ). Within this biofacies the relative percentages of $C$. cf. mimulus and $O$. expansa change so that $C$. cf. mimulus is more common at the top and $O$. expansa is more common at the bottom. The average percent planktonic foraminifers for samples belonging to this biofacies is $70 \%$.

\section{Biofacies $\boldsymbol{G}$}

This biofacies is defined by Factors 2 (16.1\% explained) and 9 ( $2.9 \%$ explained). Factor 2 is dominated by Cibicidoides subspiratus (score $=11.5$ ) and Cibicidoides cf. praemundulus (score $=4.5$; Figs. $5-8)$. Cibicidoides cocoaensis $($ score $=1.9)$, Alabamina wilcoxensis (score = 1.7), and Hanzawaia mauricensis $($ score = 1.6) are also important taxa. This biofacies dominates the lower Shark River Formation (Sequences E6 and E7) at all four boreholes. C. subspiratus is confined to these units. Van Morkhoven et al. (1986) found that $C$. subspiratus was a bathyal and abyssal species that ranged from the late early to late middle Eocene. At Island Beach, it is found in samples that are rich in carbonate $(30 \%-50 \%)$. It is not clear whether the species is tracking these high-carbonate, pelagic conditions onto the shelf or if the distribution of this species is simply not well known. The fine fraction of Biofacies G is dominated by Pyramidina subrotundata indicative of Olsson and Wise's (1987b) Biofacies 4 (estimated depth of $135 \pm 25 \mathrm{~m}$ ). The average percent planktonic foraminifers for samples belonging to this biofacies is $47.5 \%$.

Factor 9 is the least well defined biofacies and is interpreted as a subset of Biofacies G. It is dominated by Cibicidoides cf. praemundulus $($ score $=10.2)$ and Spiroplectammina alabamensis $($ score $=4.6)$ (see Fig. 13). It is found primarily in TSTs of the Shark River Formation in the ACGS\#4 borehole (Browning et al., Chapter 17, this volume) along with Factor 2. The presence of $P$. subrotundata and the abundance of Cibicidoides sp. indicate that this is equivalent to Biofacies 4 (estimated depth of $135 \pm 25 \mathrm{~m}$ ) of Olsson and Wise (1987b). The average percent planktonic foraminifers for samples belonging to this biofacies is $59 \%$. 

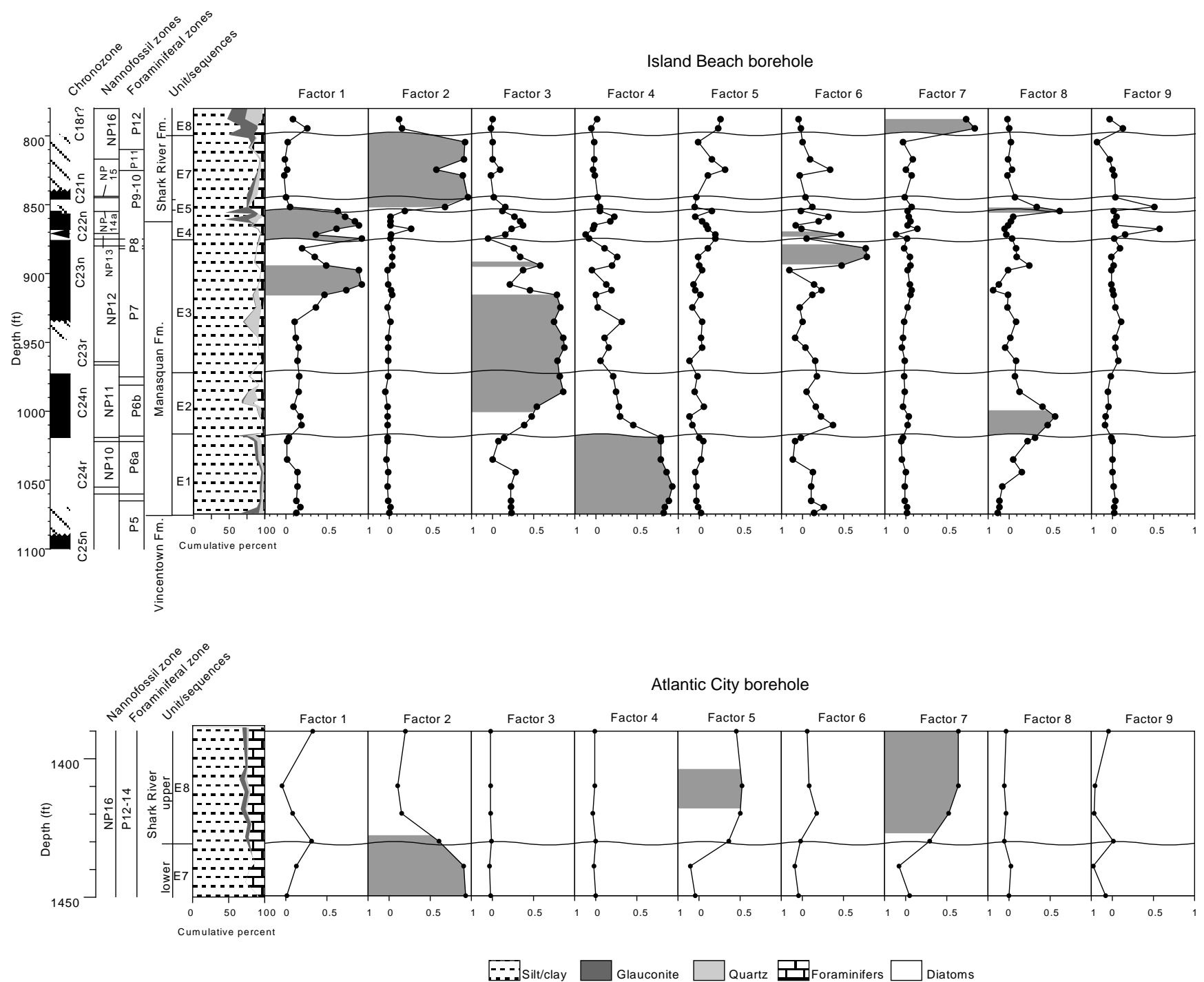

Figure 4. Distribution of lower to middle Eocene benthic foraminiferal factors found on the New Jersey Coastal Plain. Shaded areas represent sediments where a particular factor is significant.

\section{Biofacies $\boldsymbol{H}$}

This biofacies is defined by Factor 8, which explains $3.0 \%$ of the faunal variation. It is dominated by Cibicidoides eocaena (score = 11.0 ) with common Eponides sp. (score $=3.8$ ) and Gavelinella capitatus (score $=2.0$; Fig. 5). This biofacies is found in the Island Beach borehole between 1000 and $1019 \mathrm{ft}(304.8$ and $310.6 \mathrm{~m})$ in clays whose sand fraction consisted primarily of foraminifers. It is found in clay-rich sediments. The fine fraction contains abundant Trifarina wilcoxensis, indicative of Olsson and Wise's (1987b) Biofacies 5 (estimated depth of $185 \pm 25 \mathrm{~m}$ ). G. capitatus was primarily a bathyal species that also ranged into abyssal depths (van Morkhoven et al., 1986). C. eocaena was also primarily a bathyal species. The occurrence of these two species attests to the relatively great depth at which these sediments were deposited. The average percent planktonic foraminifers for samples belonging to this biofacies is $90 \%$.

\section{Cluster Analysis}

Cluster analysis was performed on the data with a Pearson correlation coefficient using the single linkage method to resolve clusters. The results of the cluster analysis and factor analysis studies are sim- ilar (Fig. 9). All groups previously identified by factor analysis were resolved by cluster analysis. Four clusters representing Factors 2 (Biofacies G), 4 (Biofacies F), 5 (Biofacies A), 7 (Biofacies B), and 9 (Biofacies G) and a sixth cluster representing the combined factors 1 (Biofacies D), 3 (Biofacies E), 6 (Biofacies C), and 8 (Biofacies H) are clearly resolved. Within the larger group, smaller clusters corresponding to Factors 1 (Biofacies D), 3 (Biofacies E), 6 (Biofacies C), and 8 (Biofacies $\mathrm{H}$ ) can be resolved. This large grouping should be expected as these factors are from the middle and upper Manasquan Formation and all occupied similar neritic environments. In addition, the ability of cluster analysis to resolve Factors 6 (Biofacies C) and 8 (Biofacies $\mathrm{H}$ ) is limited by the small number of samples attributable to these factors.

\section{Depth Model}

We infer that these biofacies inhabited different paleoenvironments on the Eocene continental shelf. Using the chronology developed for these sections by Browning et al. (Chapter 17, this volume; resolution $>0.5$ m.y.), we can compare the distribution of temporally equivalent factors (Olsson and Wise, 1987b). Because of good time control between the Island Beach and ASP boreholes (Fig. 3), it can 

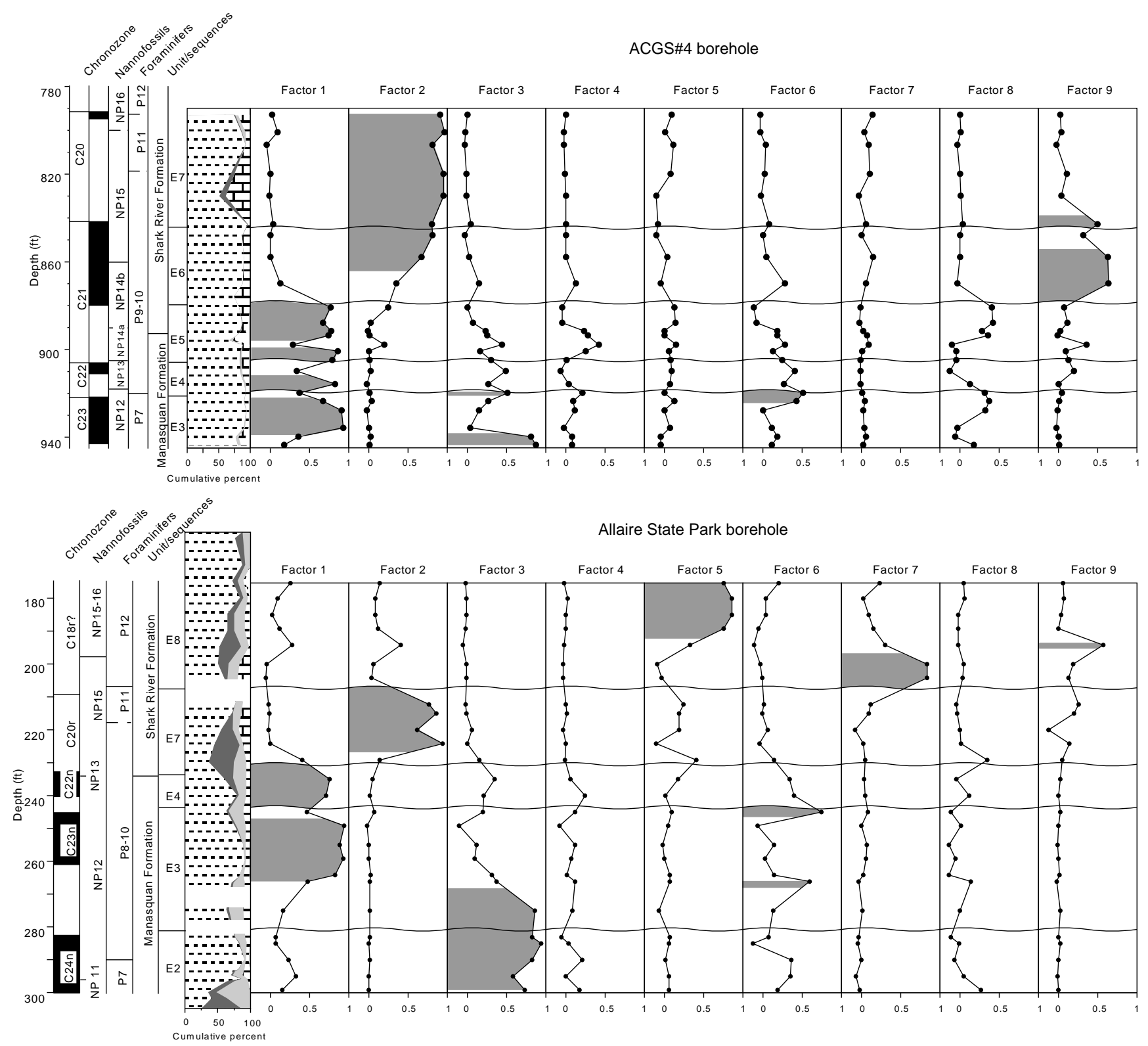

Figure 4 (continued).

be shown using depth plots (Fig. 10; see Browning et al. [Chapter 17 , this volume] for further discussion) that the changes between biofacies take place earlier at ASP than at Island Beach within a shallowing-upward sequence. Because the ASP borehole is farther updip, it is assumed that the biofacies found at ASP inhabited shallower paleowater depths that those at Island Beach. A depth profile is constructed using the changes that take place in the Deal Member (Fig. 11). The downdip distance between the ASP and Island Beach boreholes is approximately $34 \mathrm{~km}$ and, assuming the modern continental shelf gradient of 1:1000, the difference in paleodepth between the two sites would have been $34 \mathrm{~m}$. Assuming a very shallow slope of 1:2000, the difference in paleodepth would have been $17 \mathrm{~m}$, and, assuming a very steep slope of 1:500, the difference in paleodepth would have been $68 \mathrm{~m}$. Similarly, Atlantic City is $20 \mathrm{~km}$ downdip of Island Beach, meaning that it had paleodepths $20 \mathrm{~m}$ deeper, assuming a 1:1000 gradient (range from 10 to $40 \mathrm{~m}$ assuming 1:2000 and 1:500 gradients, respectively).

Biofacies $\mathrm{C}, \mathrm{D}, \mathrm{E}$, and $\mathrm{H}$ can be related to each other on a depth profile (Figs. 11, 12) using lower Eocene Sequences E2, and E3. Bio- facies $\mathrm{C}$ is the shallowest lower Eocene biofacies found in the boreholes examined here. It is generally found at the tops of the sequences in the lower Eocene and replaces Biofacies D at ASP before it replaces Biofacies D at Island Beach. Thus, Biofacies D occurs at Island Beach at the same time Biofacies C occurs at ASP (Fig. 11). Similarly, Biofacies E underlies Biofacies D in the shallowing-upwards successions and is more common at Island Beach than at ASP; it is, in part, the temporal downdip equivalent to Biofacies D (Fig. 11). The deepest biofacies found in the lower Eocene is Biofacies $\mathrm{H}$ which is found only in the Island Beach borehole at the base of Sequence E2. Samples from the base of Sequence E2 at ASP belong to Biofacies E but contain some important members of Biofacies $\mathrm{H}$. For the most part, Biofacies $\mathrm{H}$ is found at Island Beach at the same level as Biofacies E at ASP. Thus, by correlating C-D, D-E, and E-H between ASP and Island Beach, we can estimate the depth differences between the biofacies (Fig. 11).

Sediments from the upper Shark River Formation are coarser than those below. They contain abundant glauconite and siliciclastics (Fig. 3). These samples, dominated by Biofacies A and B, contain a 

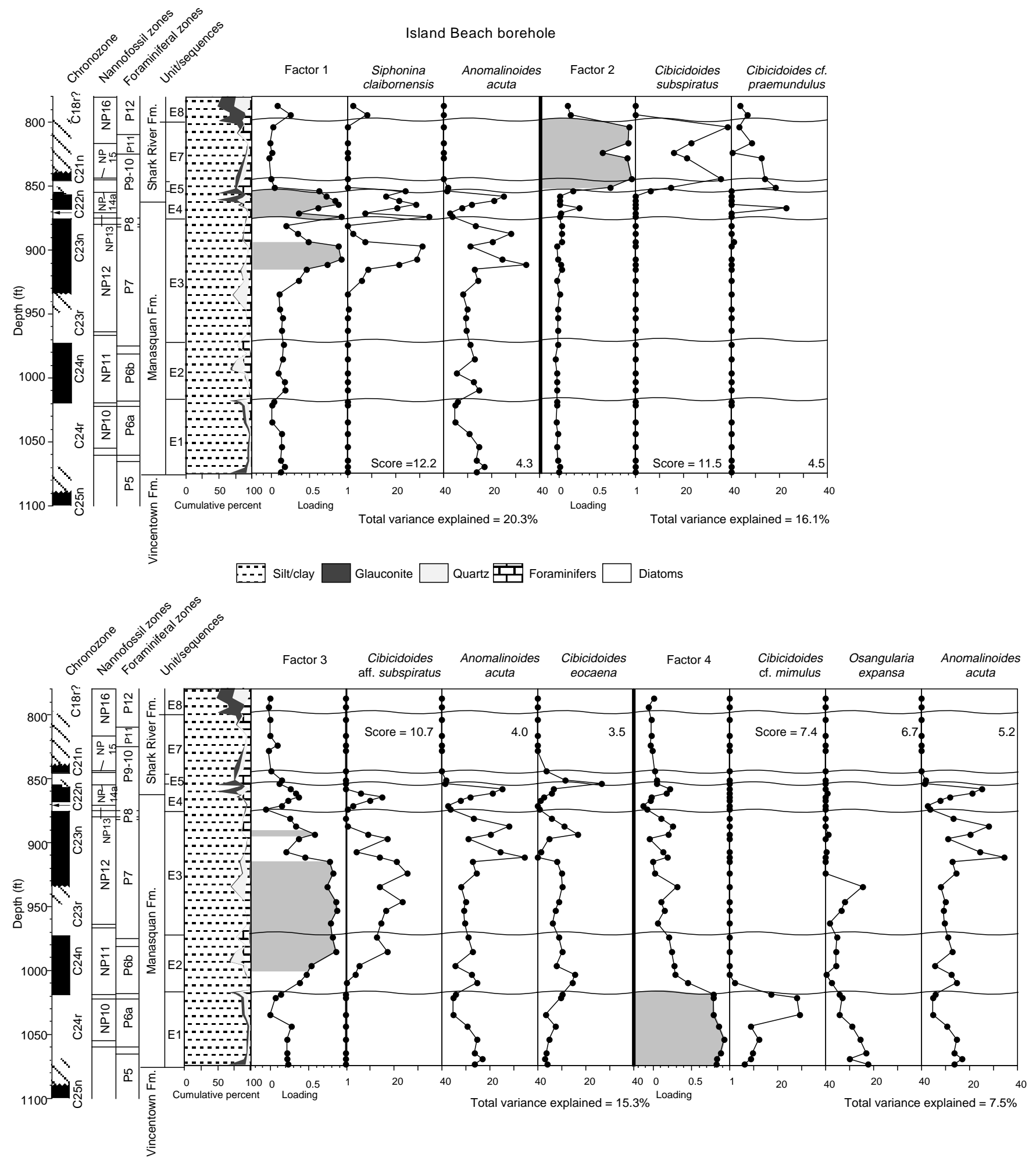

Figure 5. Factors present in the Island Beach borehole. Distribution of species with high loadings are graphed (percent of the total sample).

fauna that is notably shallower than those below. It is difficult to tie these biofacies directly to those in the samples from the Manasquan Formation. In the boreholes studied here, there is no direct overlap between the shallower and deeper biofacies. Olsson and Wise (1987b) found overlap of the shallower and deeper biofacies at the lower/middle Eocene boundary, but this event was not preserved in the boreholes studied here. Middle Eocene Sequence E8 at the Atlan- tic City borehole (upper Shark River Formation) contains Biofacies $\mathrm{B}$ which contains many of the elements found in Biofacies $\mathrm{C}$, including $C$. pseudoungerianus, Discorbis, and A. acuta. In addition, $C$. pippeni, the dominant species in Biofacies $\mathrm{B}$, accounts for only $5 \%$ of the fauna at Atlantic City. Thus, this section at Atlantic City can be used to tie the shallower (Biofacies A and B) and deeper (Biofacies $\mathrm{C}$ and $\mathrm{D}$ ) water biofacies together (Figs. 11, 12). 

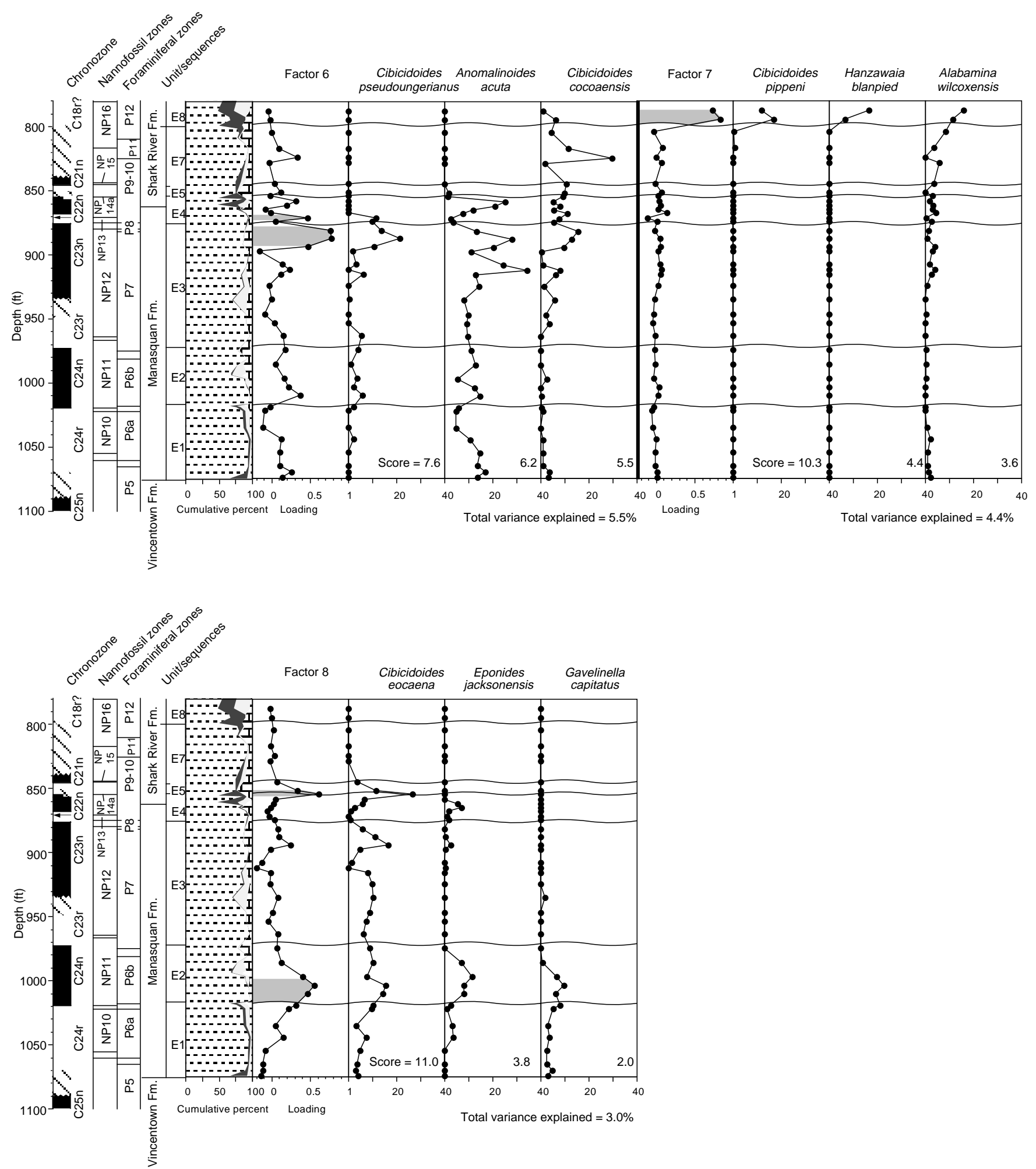

Figure 5 (continued).

Estimates of paleodepths, as opposed to relative depths, for these biofacies can vary depending on the gradient of the shelf used and the depth assumed for the shallowest biofacies. Olsson and Wise (1987b) assumed that their shallowest biofacies occurred in water depths of $\sim 50 \mathrm{~m}$, based on the percentage of planktonic foraminifers, the association with fine to medium quartz sand, and the types of benthic foraminifers present. A similar approach to the biofacies can be under- taken for this study only in a limited way because absolute depth criteria are not present. Biofacies $\mathrm{C}$ is associated predominately with clay, has abundant planktonic foraminifers $(72 \%)$, is in the middle of the depth profile, and is the shallowest of the outer neritic biofacies (Figs. 11, 12). We assume it has a depth of $100 \pm 10 \mathrm{~m}$, similar to that of Olsson and Wise (1987b). With this assumption, and an assumed 1:1000 gradient, Biofacies D would have a depth of $125 \pm 15 \mathrm{~m}$, Bio- 

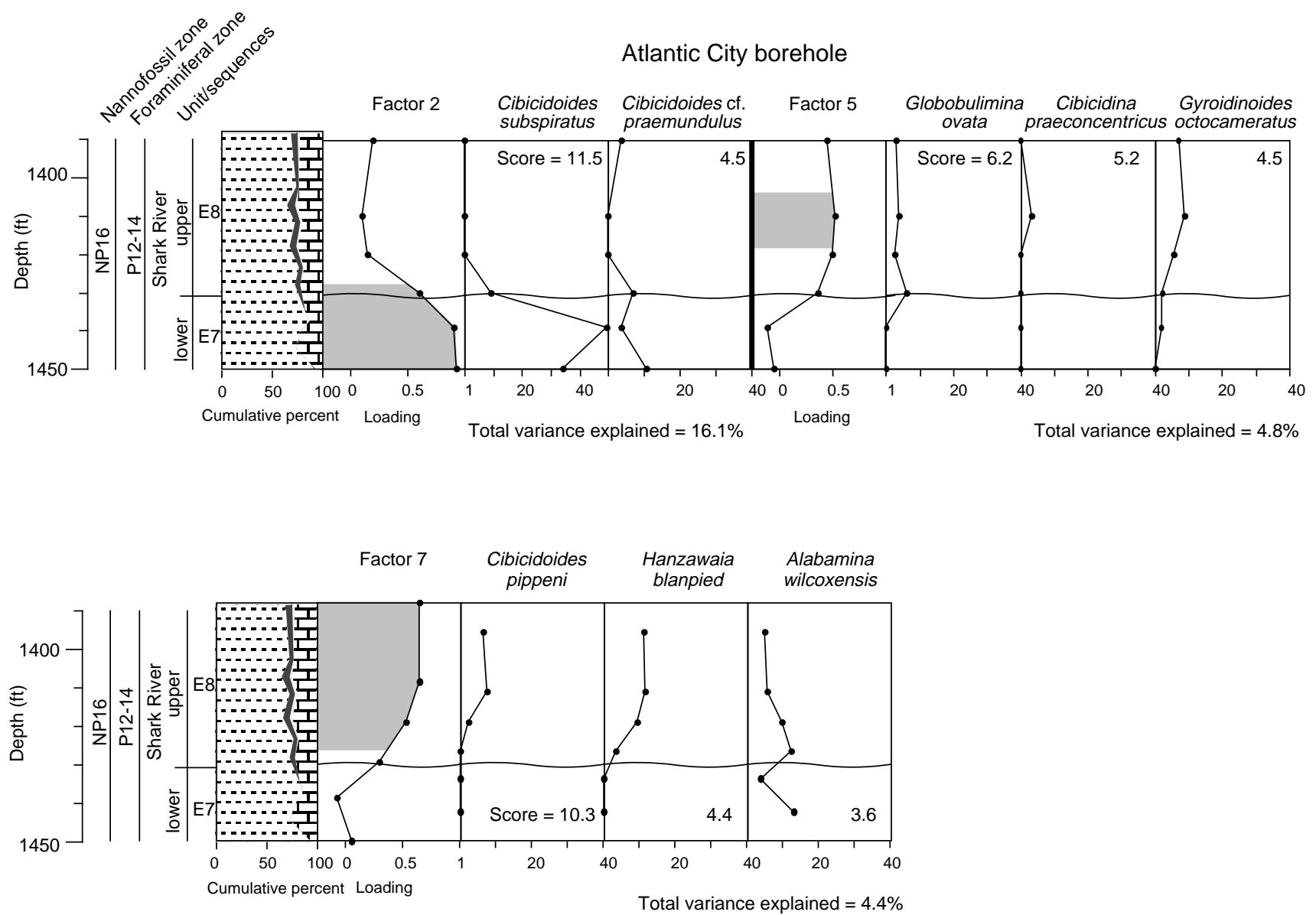

Gilt/clay $\square$ Glauconite $\square$ Quartz

Figure 6. Factors present in the Atlantic City borehole. Distribution of species with high loadings are graphed (percent of the total sample).

facies $\mathrm{E}$ would have a depth of $155 \pm 15 \mathrm{~m}$, and biofacies $\mathrm{H}$ would have a depth of $185 \pm 15 \mathrm{~m}$. The shallower biofacies are more difficult to calibrate because of their more limited occurrences. Assuming the calibration shown (Fig. 11) tying Sequence E8 biofacies with those of E3, Biofacies B would occupy water depths of $75 \pm 15 \mathrm{~m}$ and Biofacies A would occupy water depths of less than $60 \mathrm{~m}$ and probably $50 \pm 10 \mathrm{~m}$

These depth estimates for the biofacies match closely the depths given by Olsson and Wise (1987b) and differences can be ascribed to uncertainties in the methodology. This includes uncertainties in the exact line of strike, the contour of the basin, and local bottom conditions. The main difference between our results and those of Olsson and Wise (1987b) is that we divide their Biofacies 4 into two different biofacies: a shallower one dominated by Siphonina claibornensis (Biofacies D) and a deeper one dominated by $C$. aff. subspiratus (Biofacies E). Qualitative examination of the $>63$ - to $150-\mu \mathrm{m}$-size fraction reveals an abundance of $P$. subrotundata in both biofacies and both of these belong to Olsson and Wise's (1987b) Biofacies 4. All other depths compare well with those previously given (Figs. 11, 12).

The paleodepths of two biofacies ( $\mathrm{F}$ and $\mathrm{G}$ ) cannot be estimated directly because they do not overlap any of the calibrated biofacies. Our Biofacies F is only found in the Island Beach borehole in Sequence E1. Further, this study did not recover any other material that is unequivocally of the same age. Lithologically, Sequence E1 differs from Sequences E2 and E3 in that it contains more fine to very fine glauconite and quartz sand. Olsson and Wise (1987b) assigned material of this age to their Biofacies 4 and an examination of the $>63$ to $150-\mu \mathrm{m}$ fraction from sequences of Island Beach reveals an abundance of $P$. subrotundata, indicative of their Biofacies 4. Thus, we follow Olsson and Wise (1987b) and interpret biofacies $F$ to indicate a water depth $135 \pm 25 \mathrm{~m}$ (Fig. 12).

Biofacies $G$ is found only in Sequences E6 and E7 (middle Eocene). The overall taxonomic composition of this biofacies and the lithologies in which it is found are distinct. Sequences E6 and E7 are richer in carbonate ( $\sim 30 \%$ carbonate in Sequence E7 at Island Beach; Fig. 3) than other lower to middle Eocene marls, which generally contain abundant siliceous microfossils. Sequences E5 and E6 are dominated by Cibicidoides subspiratus and Cibicidoides cf. praemundulus, which are not present in other sequences. Factor 9 (a subset of Biofacies G) is only found in the ACGS\#4 borehole. Biofacies $\mathrm{G}$ is found in all boreholes, indicating that the environmental conditions favored by this biofacies were widespread at this time (early middle Eocene). Overall taxonomic composition of Biofacies $\mathrm{G}$ does change from deeper to shallower water with Cibicidoides subspiratus being more abundant at Atlantic City than at ASP. Olsson and Wise (1987b) have concluded that sediments from this time interval were deposited in water depths of $135 \pm 25 \mathrm{~m}$. All samples containing biofacies G contain abundant Pyramidina subrotundata, indicative of 


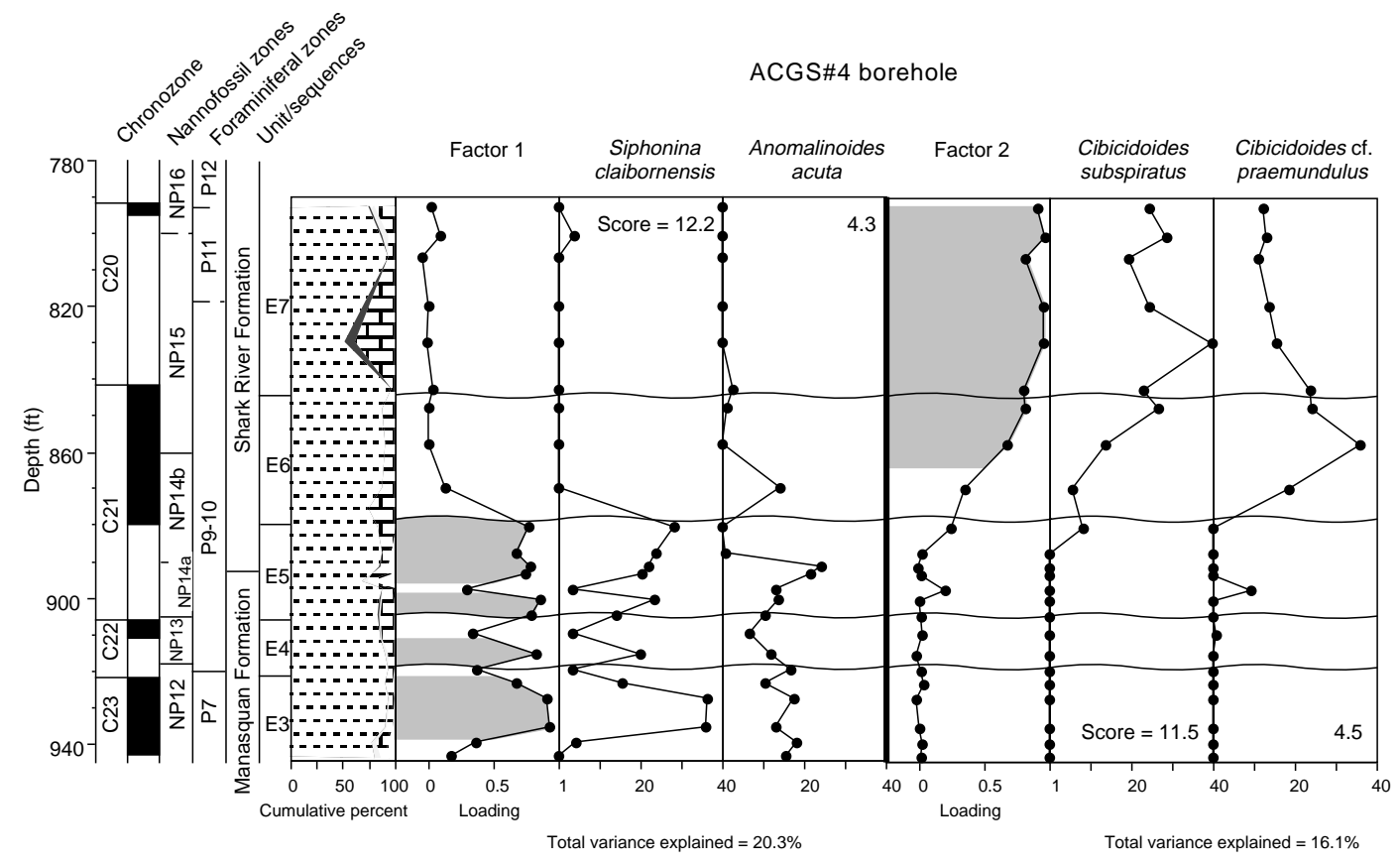

$\because-:-$ Siltclay $\square$ Glauconite $\square$ Quartz ${ }^{1}$ I F Framinifers $\square$ Diatoms

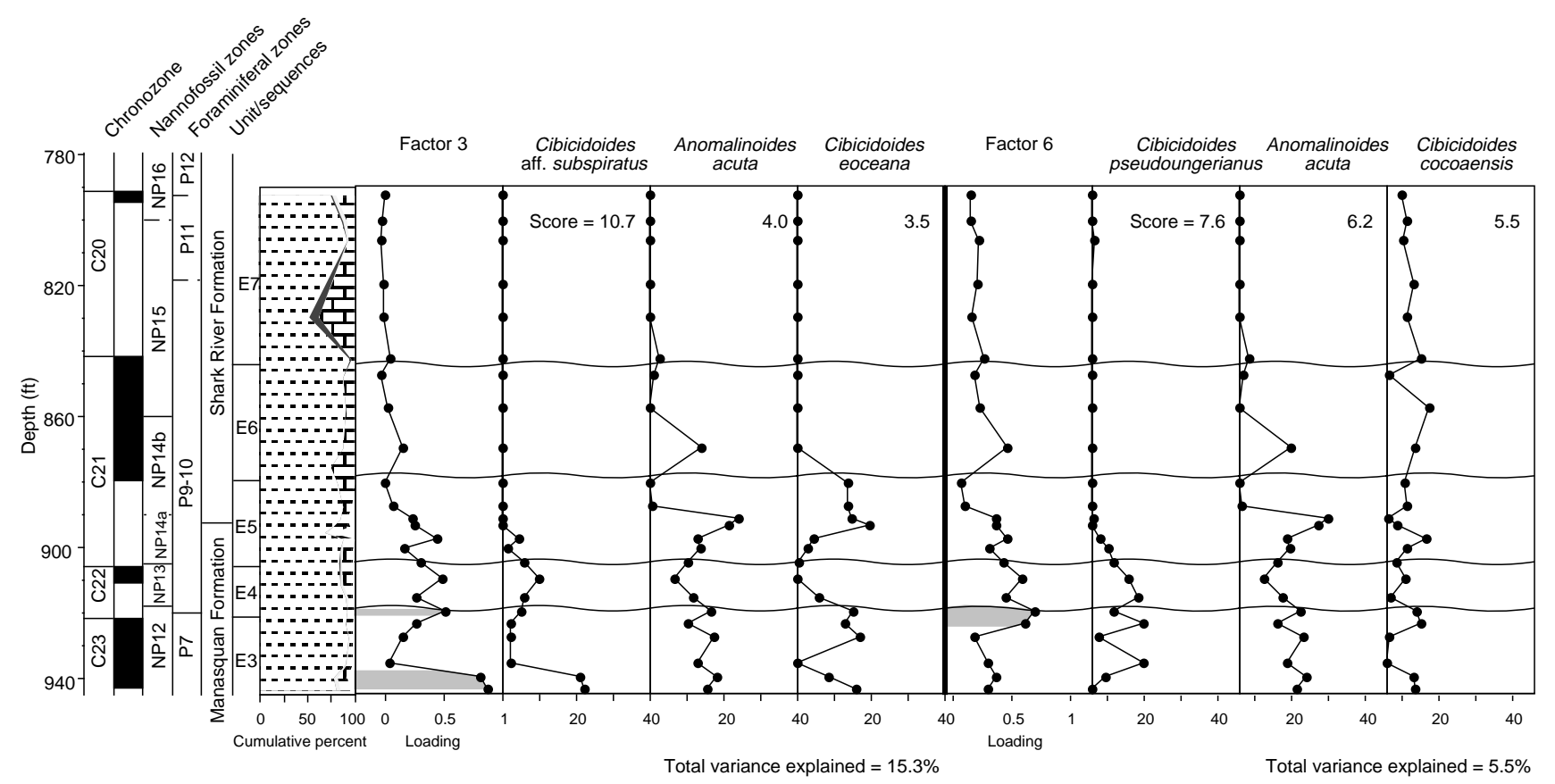

Figure 7. Factors present in the ACGS\#4 borehole. Distribution of species with high loadings are graphed (percent of the total sample). 


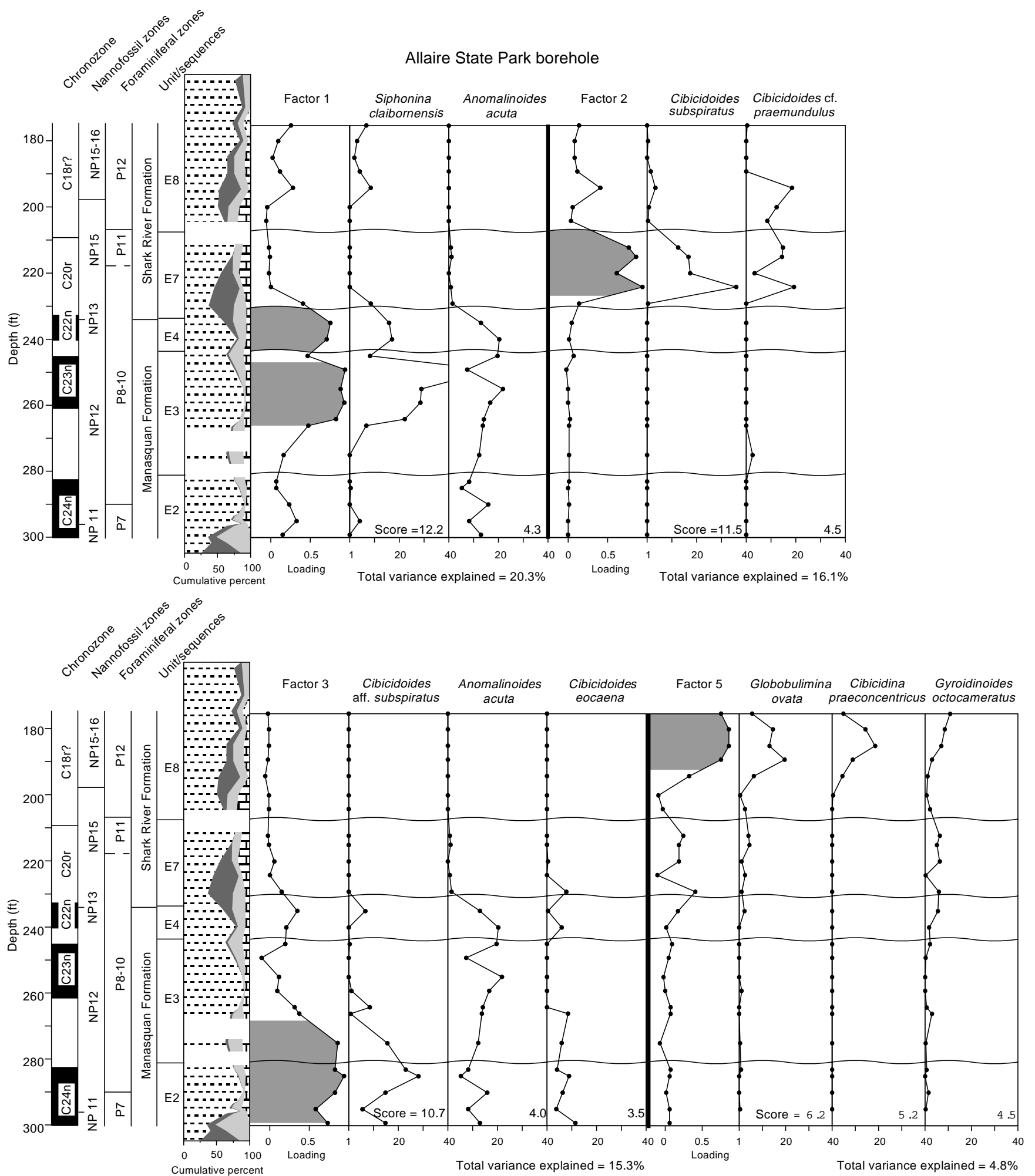

Figure 8. Factors present in the Allaire borehole. Distribution of species with high loadings are graphed (percent of the total sample). 


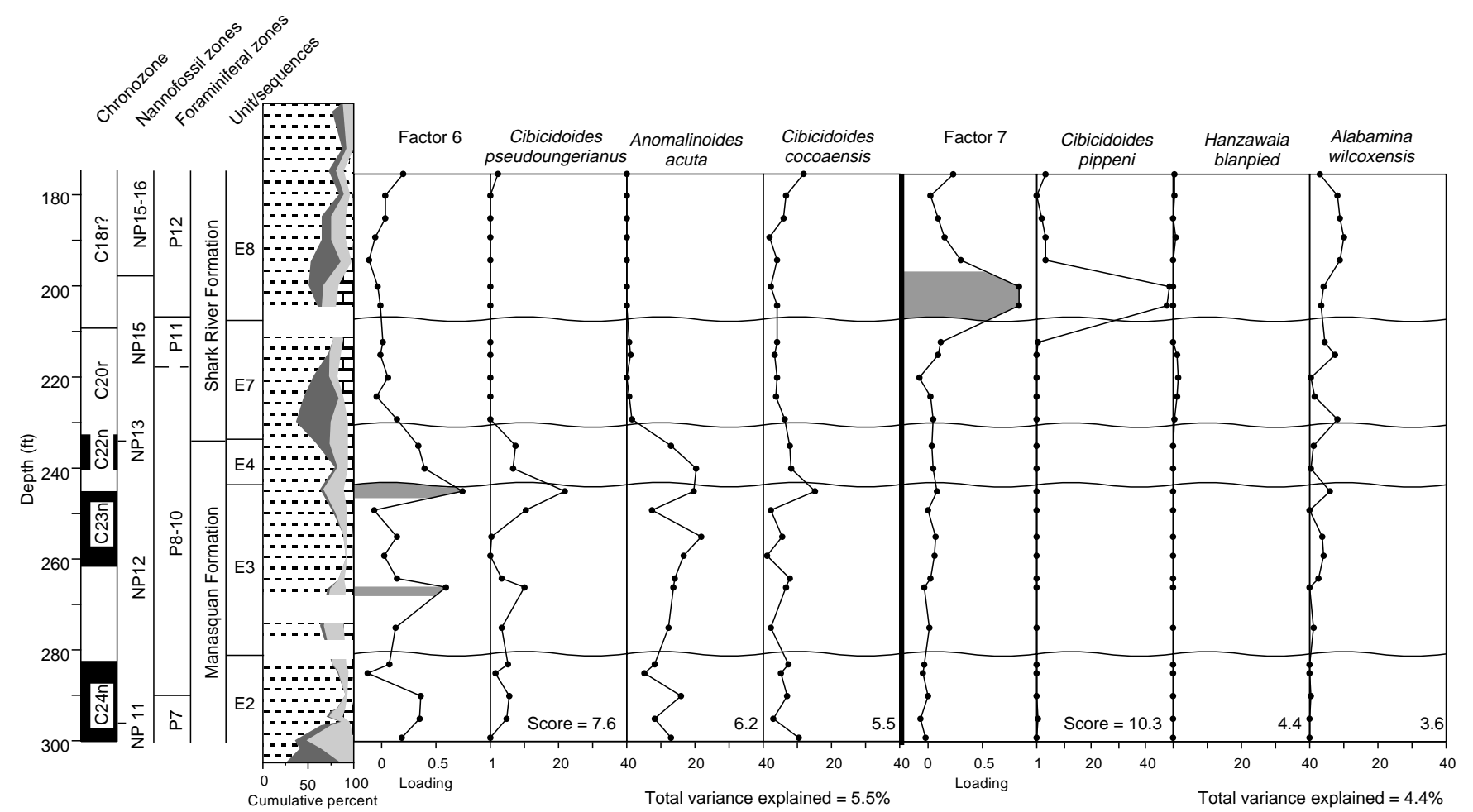

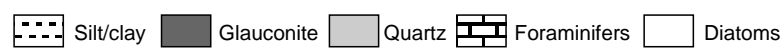

Figure 8 (continued).

water depths of $135 \pm 25 \mathrm{~m}$ (Olsson and Wise, 1987b). We conclude that biofacies $\mathrm{G}$ formed in water depths of $135 \pm 25 \mathrm{~m}$ (Fig. 12).

Based on the depth zonation inferred for the biofacies defined in this study, we derived the preferred depth range for each of the species identified in this study (Fig. 13). These distributions are based on the percent occurrence of each species in the $>150$ - $\mu \mathrm{m}$-size fraction in the different biofacies arranged according to depth. This model follows the example of Olsson and Nyong (1984). The ranges represent composites of all of those samples belonging to the same biofacies. Species whose occurrences are less than $1 \%$ in all biofacies are probably too rare to derive their preferred depth ranges.

\section{DISCUSSION}

We reconstructed New Jersey Coastal Plain early to middle Eocene paleodepth variations using benthic foraminifers tied to our paleoslope model (Figs. 11, 12). The resultant paleodepth curve has not been backstripped to produce a eustatic curve; however, the changes in water depth should be similar to the actual changes in eustasy except for the loading effects of sediment and water, which result in water-depth changes that overestimate eustatic changes by approximately one third (Steckler and Watts, 1978). It is difficult to make generalizations about overall sea-level change because of the erosion and nondeposition of sediment associated with hiatuses at sequence boundaries. Most of the preserved sediments are TSTs and HSTs, and there is no water-depth information preserved from the lowstand systems tracts. Interpolation of water depth between the preserved sections is speculative (Fig. 14), although the lack of nearshore facies in any of the sequences is taken to indicate that water depths were never much shallower than $50 \mathrm{~m}$. We infer that water depth stood at $\sim 130 \mathrm{~m}$ above present during most of the early to middle Eocene (Fig. 14). Greatest water depths of approximately $180 \mathrm{~m}$ at Island Beach were attained in the early Eocene (Sequence E2; Fig. 14), probably because of sediment starvation, which increased accommodation space. These results are comparable to the results derived by Poag and Low (1987). They showed water depths of 150$250 \mathrm{~m}$ at Island Beach and 100-150 at ASP for the early Eocene.

Evidence indicates that there were many small relative sea-level events and deposition of several sequences around the early/middle Eocene boundary (Fig. 14). One of these includes a major sea-level fall interpreted by Olsson and Wise (1987b) to have been $90 \mathrm{~m}$ (Fig. 14). Water depth increased again in the middle Eocene, attaining depths of over $150 \mathrm{~m}$. In the late middle Eocene (Sequence E8), it fell to $\sim 60-75 \mathrm{~m}$ at Island Beach (Fig. 14).

The New Jersey water-depth curve is similar to the eustatic curve of Haq et al. (1987) (Fig. 14). Haq et al. (1987) show consistently high sea levels (200 m above modern sea level) throughout most of the early to middle Eocene, although they do not show a eustatic increase similar to the water-depth increase recorded in Sequence E2 (Fig. 14). They also indicate a shallowing similar to that found in the upper Shark River Formation. Detailed differences between the curves exist because of uncertainties in correlations. Browning et al. (Chapter 17, this volume) show that there are minor differences in age between the Haq et al. and New Jersey sequences.

No obvious mechanism exists to account for the formation of lower Eocene unconformities in New Jersey. Under existing models, sequence boundaries are formed during a regional lowering of baselevel by either subaerial erosion (Christie-Blick and Driscoll, 1995) or shore-face erosion producing a ravinement surface (Suter et al., 1987). Deeper water sections are inferred to contain a correlative conformity (Posamentier et al., 1988). New Jersey Oligocene (Pekar et al., Chapter 15, this volume) and Miocene (Miller et al., Chapter 14, this volume) sequences commonly contain inner neritic sedimentary facies at the bases of sequences consistent with subaerial, shore-face, or storm-wave erosion being responsible for sequence-boundary for- 


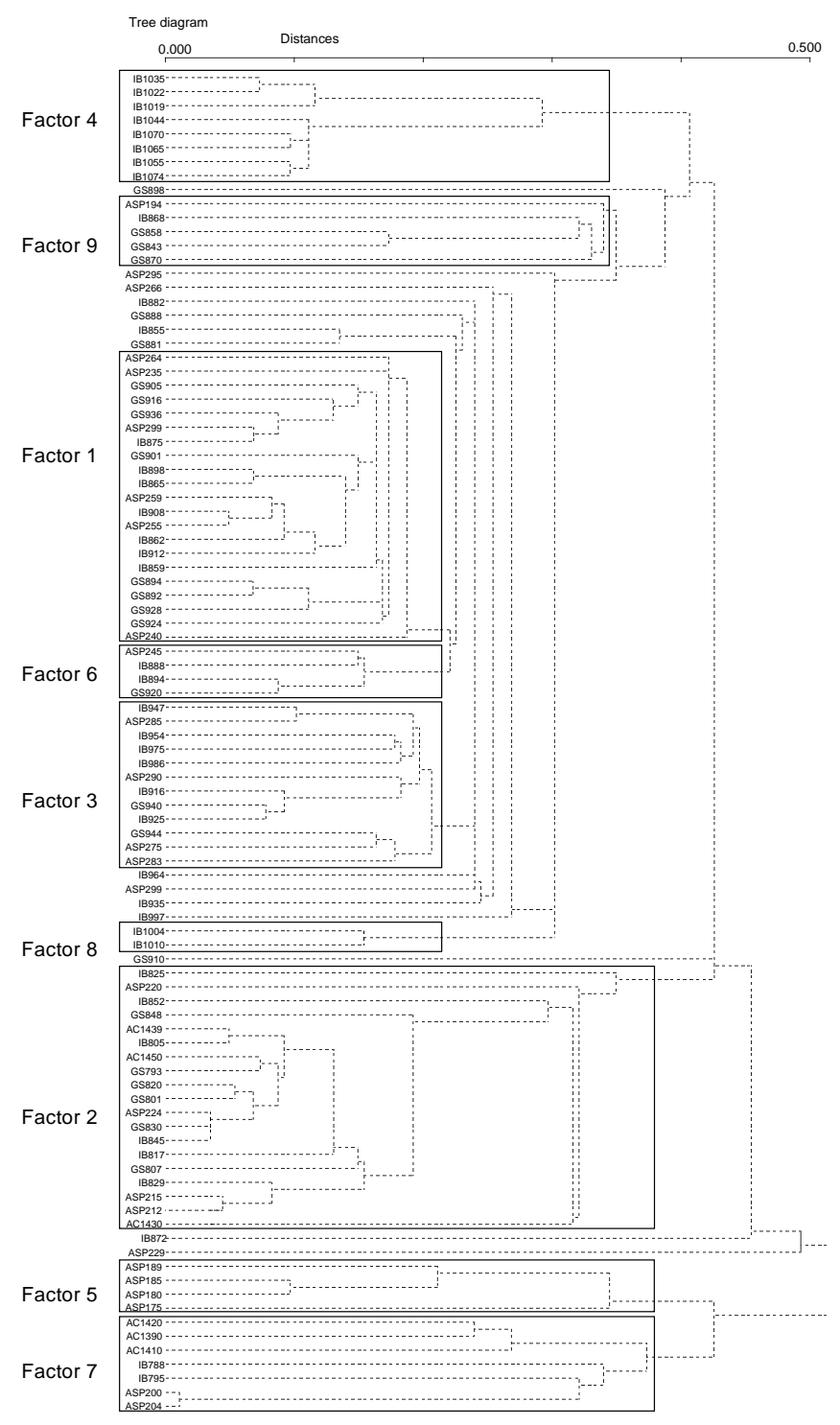

Figure 9. Cluster diagram using a Pearson correlation coefficient and single linkage method to resolve clusters. Boxes show related clusters and are related to biofacies determined by factor analysis.

mation. The lower to middle Eocene sequences documented here accumulated in relatively deep water $(>50 \mathrm{~m})$ and near-shore and inner neritic sedimentary facies are absent. Although water depths at the times of the lowstand systems tracts are unknown, the lack of nearshore facies argues against subaerial erosion or ravinement. Such deep-water "sequence boundaries" have been attributed to submarine erosion by transgressive surfaces (Poag and Ward, 1993; Poag and Commeau, 1995) or starvation associated with flooding surfaces (see summary in Mancini et al., 1987). We cannot unequivocally demonstrate that our "sequence boundaries" are caused by lowerings of baselevel. However, good correlation between our lower Eocene sequence boundaries and the Haq et al. (1987) eustatic record provides evidence that they are, in fact, global lowerings of baselevel. The correlative conformity evidently forms in water depths deeper than those documented here.

If the sequence delineated in the New Jersey Eocene results from global lowerings of sea level, then the mechanism causing these changes in unclear. The only known mechanism that can cause the large, rapid sea-level changes (Fig. 14) observed in the New Jersey
Eocene is glacioeustatic change. Browning et al. (Chapter 17, this volume) demonstrate that there is no correlation between the timing of lower Eocene unconformities and the $\delta^{18} \mathrm{O}$ proxy for ice-volume changes, although late middle Eocene sequence boundaries are linked to glacioeustatic lowerings (Browning et al., 1996; Chapter 17 , this volume). We conclude that the mechanisms that caused the large, rapid sea-level changes during the early Eocene are unknown.

\section{CONCLUSION}

Using integrated stratigraphy, Browning et al. (Chapter 17, this volume) divided the lower to middle Eocene New Jersey Coastal Plain sediments into eight sequences. A typical Eocene sequence consists of a thin glauconite-rich clay at the base followed by clays above that become slightly sandy at the top. In this study we evaluate lithostratigraphic units defined in outcrops and updip sections, determine their relationships to these sequences, and use benthic foraminifers to evaluate water-depth changes within and between sequences. We distinguish benthic foraminiferal biofacies using factor analysis and assign water depths to each of these biofacies using the paleoslope modeling technique of Olsson and Nyong (1984). In the lower to middle Eocene section, we distinguish eight benthic foraminiferal biofacies that inhabited water depths ranging from $\sim 50$ to $200 \mathrm{~m}$. Water depths were $\sim 130 \mathrm{~m}$ during most of this interval. Maximum water depths $(185 \pm 15 \mathrm{~m})$ were attained in the early Eocene, and sea level fell to $50 \pm 10 \mathrm{~m}$ in the middle Eocene. Most changes in water depth are similar in timing and magnitude to those proposed by Haq et al. (1987). In the absence of ice sheets, these large and rapid sea-level changes are difficult to explain.

\section{ACKNOWLEDGMENTS}

We thank C. Liu, S. Pekar, and P. Sugarman for discussions, and T. Gibson, W. Poag, and R.Z. Poore for reviews. We also thank D. Ostermann for supplying the carbonate data. This study was supported by National Science Foundation Grants EAR92-18210 and EAR94-17108. This is Lamont-Doherty Earth Observatory contribution 5689.

\section{REFERENCES}

Bandy, O.L., 1949. Eocene and Oligocene foraminifera from Little Stave Creek, Clarke County, Alabama. Bull. Am. Paleontol., 32:1-211.

1953a. Ecology and paleoecology of some California foraminifera; Part I, the frequency distribution of Recent foraminifera off California. J. Paleontol., 27:161-182.

1953b. Ecology and paleoecology of some California foraminifera; Part II, foraminiferal evidence of subsidence rates in the Ventura basin. J. Paleontol., 27:183-203.

Berggren, W.A., Kent, D.V., Swisher, C.C., III, and Aubry, M.-P., 1995. A revised Cenozoic geochronology and chronostratigraphy. In Berggren, W.A., Kent, D.V., Aubry, M.-P., and Hardenbol, J. (Eds.), Geochronology, Time Scales and Global Stratigraphic Correlation. Spec. Publ.Soc. Econ. Paleontol. Mineral., 54:129-212.

Bolli, H.M., 1957a. The genera Globigerina and Globorotalia in the Paleocene-lower Eocene Lizard Springs Formation of Trinidad, B.W.I. In Loeblich, A.R., Jr. (Ed.), Studies in Foraminifera. Bull.-U.S. Nat. Mus., 215:61-81.

, 1957b. Planktonic foraminifera from the Eocene Navet and San Fernando formations of Trinidad, B.W.I. In Loeblich, A.R., Jr. (Ed.), Studies in Foraminifera. Bull.-U.S. Nat. Mus., 215:155-172.

Browning, J.V., 1996. Eocene sequences and benthic foraminiferal biofacies on the New Jersey coastal plain [Ph.D. dissert.]. Rutgers University, New Brunswick, NJ.

Browning, J.V., Miller, K.G., and Pak, D.K., 1996. Global implications of lower to middle Eocene sequence boundaries on the New Jersey Coastal Plain-The Icehouse cometh. Geology, 24:639-642. 
Charletta, A.C., 1980. Eocene benthic foraminiferal paleoecology and paleobathymetry of the New Jersey continental margin [Ph.D. dissert.]. Rutgers Univ., New Brunswick, NJ.

Christensen, B.A., Miller, K.G., and Olsson, R.K., 1995. Eocene-Oligocene benthic foraminiferal biofacies and depositional sequences at the ACGS\#4 borehole, New Jersey Coastal Plain. Palaios, 10:103-132.

Christie-Blick, N., and Driscoll, N.W., 1995. Sequence stratigraphy. Ann. Rev. Earth Planet. Sci., 23:451-478.

Clark, W.B., 1894. Cretaceous and Tertiary geology; report of progress. Ann. Rep. State Geol., New Jersey Geol. Surv.

Conrad, T.A., 1865. Observations on the Eocene lignite formation of the United States. Proc. Acad. Sci. Philadelphia, 17:70-73.

Cook, G.H., 1868. The geology of New Jersey. Geol. Surv. New Jersey, 263242.

Douglas, R.G., 1979. Benthic foraminiferal ecology and paleoecology: a review of concepts and methods. In Lipps, J.H., Berger, W.H., Buzas, M.A., Douglas, R.G., and Ross, C.A. (Eds.), Foraminiferal Ecology and Paleoecology: Soc. Econ. Paleontol. Mineral., SEPM Short Course Notes, 6:11-20.

Enright, R., 1969a. The stratigraphy and clay mineralogy of Eocene sediments of the northern New Jersey Coastal Plain. In Subitsky, S., (Ed.), Geology of selected areas in New Jersey and eastern Pennsylvania and guidebook of excursions: New Brunswick, NJ (Rutgers University Press), 14-20.

, 1969b. The stratigraphy, micropaleontology, and paleoenvironmental analysis of the Eocene sediments of the New Jersey Coastal Plain [Ph.D. dissert.]. Rutgers Univ., New Brunswick, NJ.

Gibson, T.G., Bybell, L.M., and Owens, J.P., 1993. Latest Paleocene lithologic and biotic events in neritic deposits of southwestern New Jersey. Paleoceanography, 8:495-514.

Haq, B.U., Hardenbol, J., and Vail, P.R., 1987. Chronology of fluctuating sea levels since the Triassic. Science, 235:1156-1167.

Jones, G.D., 1983. Foraminiferal biostratigraphy and depositional history of the Middle Eocene rocks of the coastal plain of North Carolina. North Carolina Geol. Surv. Spec. Publ., 8:1-80.

Mancini, E.A., Tew, B.H., and Waters, L.A., 1987. Eocene-Oligocene boundary in southeastern Mississippi and southwestern Alabama: a stratigraphically condensed section of a type 2 depositional sequence. In Ross, C.A., and Haman, D. (Eds.), Timing and Depositional History of Eustatic Sequences: Constraints on Seismic Stratigraphy. Spec. Publ.-Cushman Found. Foraminiferal Res., 24:41-50.

Miller, K.G., Browning, J.V., Liu, C., Sugarman, P., Kent, D.V., Van Fossen, M., Queen, D., Goss, M., Gwynn, D., Mullikin, L., Feigenson, M.D., Aubry, M.-P., and Burckle, L.D., 1994a. Atlantic City site report. In Miller, K.G., et al., Proc. ODP, Init. Repts., 150X: College Station, TX (Ocean Drilling Program), 35-55.

Miller, K.G., Kent, D.V., Brower, A.N., Bybell, L.M., Feigenson, M.D., Olsson, R.K., and Poore, R.Z., 1990. Eocene-Oligocene sea-level changes on the New Jersey coastal plain linked to the deep-sea record. Geol. Soc. Am. Bull., 102:331-339.

Miller, K.G., Sugarman, P., Van Fossen, M., Liu, C., Browning, J.V., Queen, D., Aubry, M.-P., Burckle, L.D., Goss, M., and Bukry, D., 1994b. Island Beach site report. In Miller, K.G., et al., Proc. ODP, Init. Repts., 150X: College Station, TX (Ocean Drilling Program), 5-33.

Miller, K.G., Wright, J.D., and Fairbanks, R.G., 1991. Unlocking the Ice House: Oligocene-Miocene oxygen isotopes, eustasy, and margin erosion. J. Geophys. Res., 96:6829-6848.

Murray, J.W., 1991. Ecology and Palaeoecology of Benthic Foraminifera: London (Longman).

Olsson, R.K., Melillo, A.J., and Schreiber, B.L., 1987. Miocene sea level events in the Maryland Coastal Plain and the offshore Baltimore Canyon Trough. In Ross, C., and Haman, D. (Eds.), Timing and Depositional History of Eustatic Sequences: Constraints on Seismic Stratigraphy. Spec. Publ. Cushman Found. Foraminiferal Res., 24:85-97.

Olsson, R.K., and Nyong, E.E., 1984. A paleoslope model for CampanianLower Maestrichtian foraminifera of New Jersey and Delaware. J. Foraminiferal Res., 14:50-68.

Olsson, R.K., and Wise, S.W., 1987a. Upper Maestrichtian to middle Eocene stratigraphy of the New Jersey slope and coastal plain. In van Hinte, J.E., Wise, S.W., Jr., et al., Init. Repts. DSDP, 93 (Pt. 2): Washington (U.S. Govt. Printing Office), 1343-1365. 1987b. Upper Paleocene to middle Eocene depositional sequences and hiatuses in the New Jersey Atlantic Margin. In Ross, C., and Haman, D. (Eds.), Timing and Depositional History of Eustatic Sequences: Constraints on Seismic Stratigraphy. Spec. Publ. Cushman Found. Foraminiferal Res., 24:99-112.

Ostermann, D.R., Karbott, D., and Curry, W.B., 1990. Automated system to measure the carbonate concentration of sediments. WHOI Tech. Rep., 90-103.

Owens, J.P., Bybell, L.M., Paulachok, G., Ager, T.A., Gonzalez, V.M., and Sugarman, P.J., 1988. Stratigraphy of the Tertiary sediments in a 945foot-deep core hole near Mays Landing in the southeastern New Jersey Coastal Plain. Geol. Surv. Prof. Pap. U.S., 1484.

Poag, C.W., and Aubry, M.-P., 1995. Upper Eocene impactites of the U.S. coast: depositional origins, biostratigraphic framework, and correlation. Palaios, 10:16-43.

Poag, C.W., and Commeau, J.A., 1995. Paleocene to middle Miocene planktic Foraminifera of the southwestern Salisbury Embayment, Virginia and Maryland: biostratigraphy, allostratigraphy, and sequence stratigraphy. $J$. Foraminiferal Res., 25:134-155

Poag, C.W., and Low, D., 1987. Unconformable sequence boundaries at Deep Sea Drilling Project Site 612, New Jersey Transect: their characteristics and stratigraphic significance. In Poag, C.W., Watts, A.B., et al., Init. Repts. DSDP, 95: Washington (U.S. Govt. Printing Office), 453498.

Poag, C.W., Powars, D.S., Poppe, L.J., Mixon, R.B., Edwards, L.E., Folger, D.W., and Bruce, S., 1992. Deep Sea Drilling Project Site 612 bolide event: new evidence of a late Eocene impact-wave deposit and a possible impact site, U.S. east coast. Geology, 20:771-774.

Poag, C.W., and Ward, L.W., 1993. Allostratigraphy of the U.S. middle Atlantic continental margin-characteristics, distribution, and depositional history of principal unconformity-bounded upper Cretaceous and Cenozoic sedimentary units. Geol. Surv. Prof. Pap. U.S., 1542.

Poore, R.Z., and Bybell, L.M., 1988. Eocene to Miocene biostratigraphy of New Jersey core ACGS \#4: implications for regional stratigraphy. Geol. Surv. Prof. Pap. U.S., 1829.

Posamentier, H.W., Jervey, M.T., and Vail, P.R., 1988. Eustatic controls on clastic deposition, I. Conceptual framework. In Wilgus, C.K., Hastings, B.S., Ross, C.A., Posamentier, H.W., Van Wagoner, J., and Kendall, C.G.St.C. (Eds.), Sea-Level Changes: An Integrated Approach. Spec. Publ.-Soc. Econ. Paleontol. Mineral., 42:109-124.

Steckler, M.S., and Watts, A.B., 1978. Subsidence of Atlantic-type continental margin off New York. Earth Planet. Sci. Lett., 41:1-13.

Sugarman, P.J., Miller, K.G., Owens, J.P., and Feigenson, M.D., 1993. Strontium isotope and sequence stratigraphy of the Miocene Kirkwood Formation, Southern New Jersey. Geol. Soc. Am. Bull., 105:423-436.

Sugarman, P.J., Owens, J.P., and Bybell, L.M., 1991. Geologic map of the Adelphia and Farmingdale Quadrangles, Monmouth and Ocean Counties, New Jersey. NJ Geol. Surv., Geol. Map Series, 91-1.

Suter, J.R., Berryhill, Jr., H.L., and Penland, S., 1987. Late Quaternary sealevel fluctuations and depositional sequences, southwest Louisiana continental shelf. In Nummedal, D., Pilkey, O.H., and Howard, J.D. (Eds.), Sea-Level Fluctuation and Coastal Evolution. Spec. Publ.-Soc. Econ. Paleontol. Mineral., 41:199-219.

Thein, J., 1987. A tektite layer in upper Eocene sediments of the New Jersey continental slope (Site 612, Leg 95). In Poag, C.W., Watts, A.B., et al., Init. Repts. DSDP, 95: Washington (U.S. Govt. Printing Office), 565579.

Tjalsma, L., and Lohmann, G., 1983. Paleocene-Eocene bathyal and abyssal benthic foraminifera from the Atlantic Ocean. Micropaleontol., Spec. Publ., 4:1-90.

Van Morkhoven, F.P.C.M., Berggren, W.A., and Edwards, A.S., 1986. Cenozoic Cosmopolitan Deep-Water Benthic Foraminifera. Bull. Cent. Rech. Explor-Prod. Elf-Aquitaine, Mem. 11.

Date of initial receipt: 1 February 1996

Date of acceptance: 18 October 1996

Ms 150XSR-333 


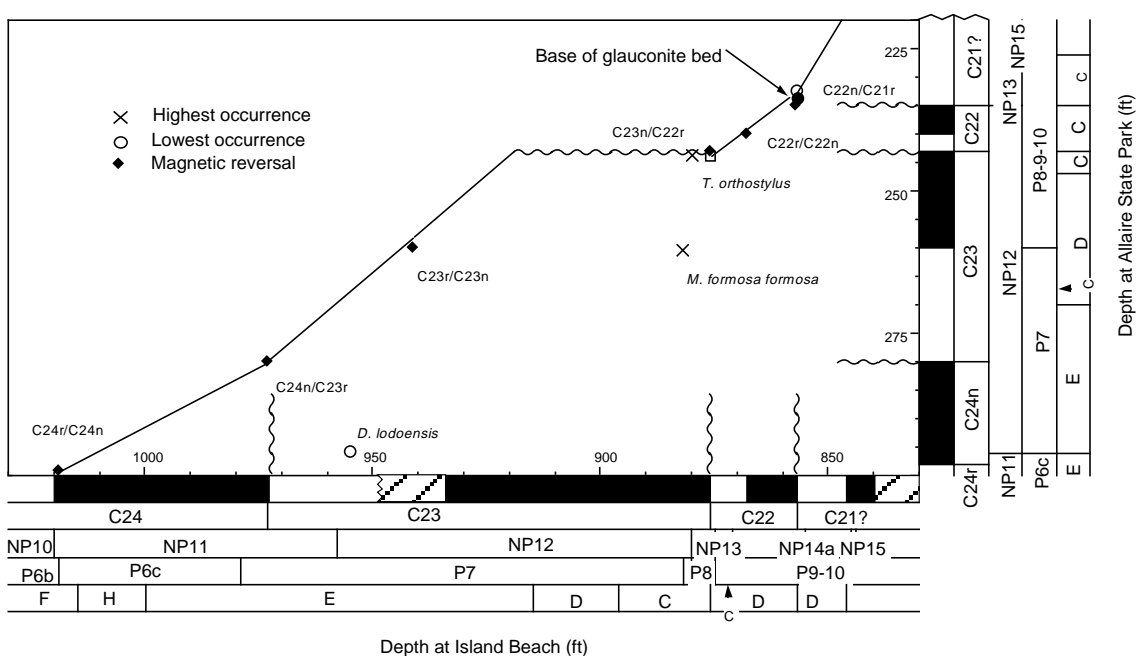

Figure 10. Comparison of the Allaire and Island Beach boreholes as a function of depth below surface, using age-significant bioevents and magnetic reversals to correlate the cores. Wavy lines indicate unconformities. Capital letters indicate benthic biofacies that are defined in the text.

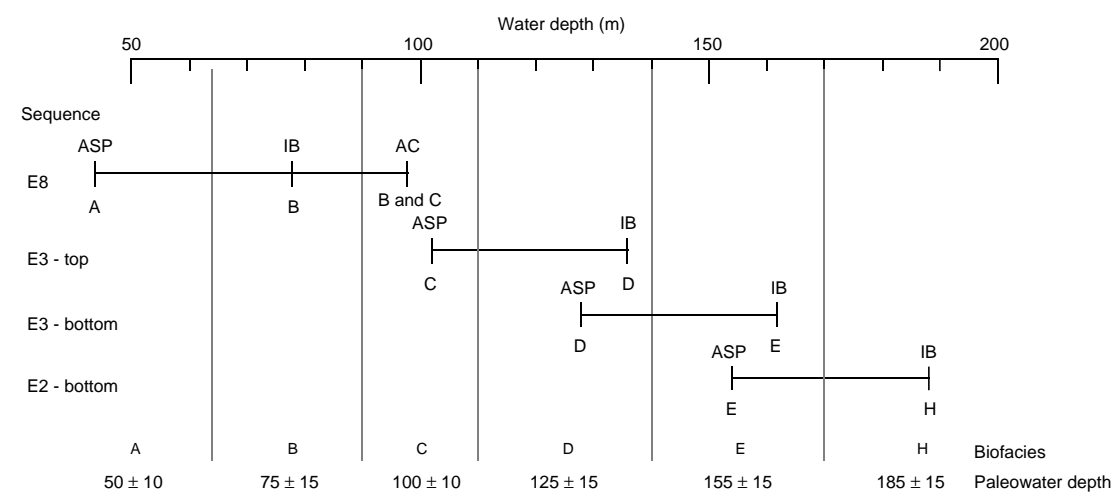

Figure 11. Integration of the lower to middle Eocene benthic foraminiferal biofacies onto a paleoslope. Depths are derived assuming a paleoslope of 1:1000 between boreholes. ASP is Allaire State Park. IB is Island Beach. AC is Atlantic City. 
Lower to middle Eocene benthic foraminiferal biofacies - New Jersey coastal plain

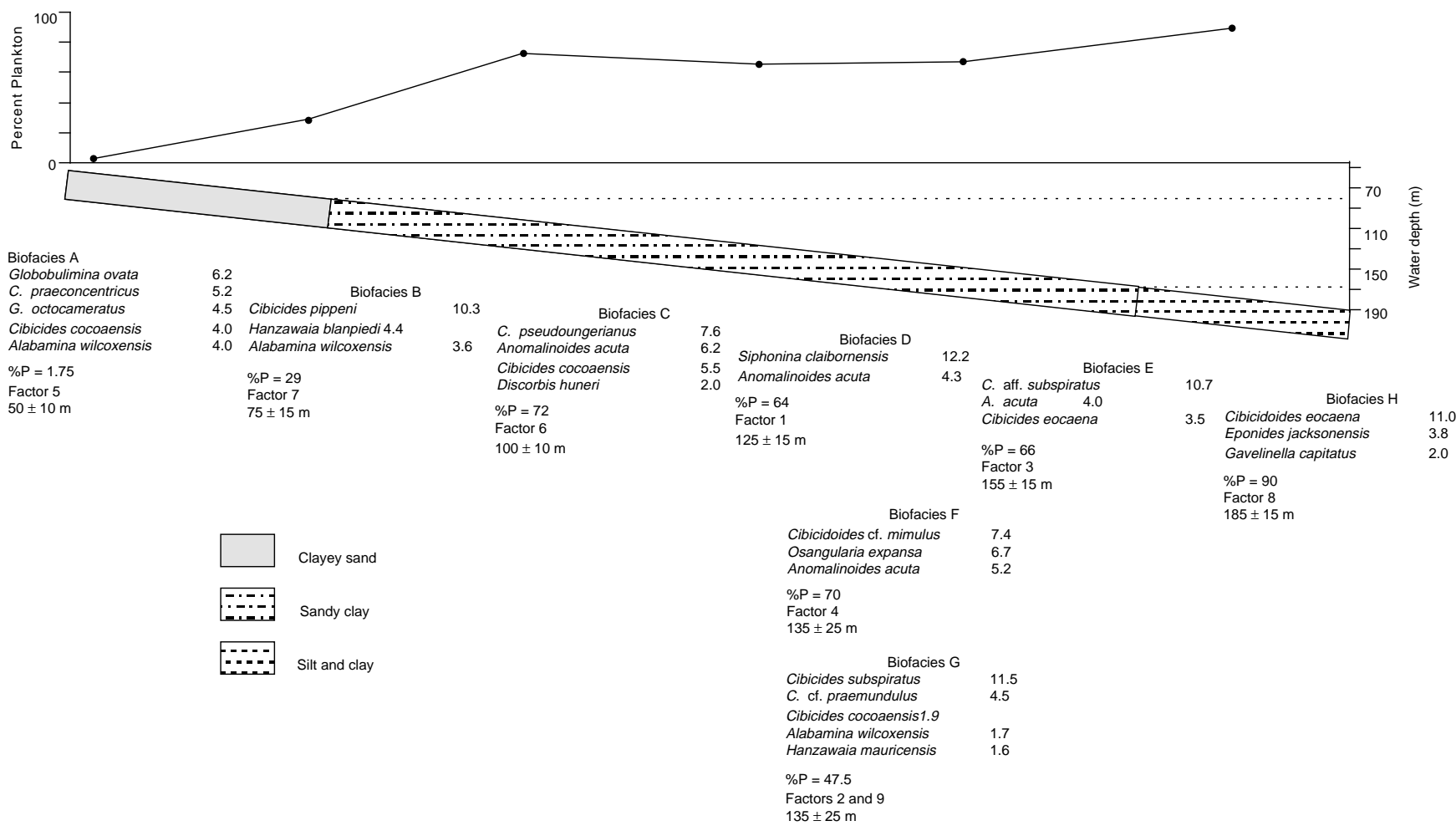

Figure 12. Paleobathymetry of the New Jersey lower to middle Eocene benthic foraminifers. $\% \mathrm{P}=$ average percent planktonic foraminifers. 
Globobulimina ovata

Alabamina wilcoxensis

Cibicides cocoaensis

Cibicidina praeconcentricus

Gyroidinoides octocameratus

Cibicides howelli

Hanzawaia mauricensis

Eponides jacksonensis

Siphonina claibornensis

Melonis barleanum

Cibicidina mississippiensis

Stilostomella cocoaensis

Cibicides lobata

Cibicides vicksburgensis

Ceratocancris sp.

Lenticulina limbosus

Valvulineria texana

Pararotalia inconspicua

Globulina gibba

Guttulina irregularis

Lenticulina carolinianus

Lenticulina jugosus

Nonionellina winniana

Cibicides pippeni

Pseudobulimina glaessneri

Cibicides subspiratus

Ramulina globulifera

Cibicides ungerianus

Fursenkoina huneri

Fursenkoina zetina

Dentalina vertabralis albatrossi

Cibicides cf. praemundulus

Astigerina texana

Hanzawaia blanpiedi

Anomalinoides costiana

Lenticulina midwayensis

Loxostomum claibornensis

Karreriella mauricensis

Nodosaria latejugata

Uvigerina elongata

Pullenia quinqeloba

Discorbis huneri

Spiroplectammina mississippiensis

Lenticulina alato-limbatus

Biofacies (this study)

Olsson and Wise (1987b) biofacies
Lagena multicostata

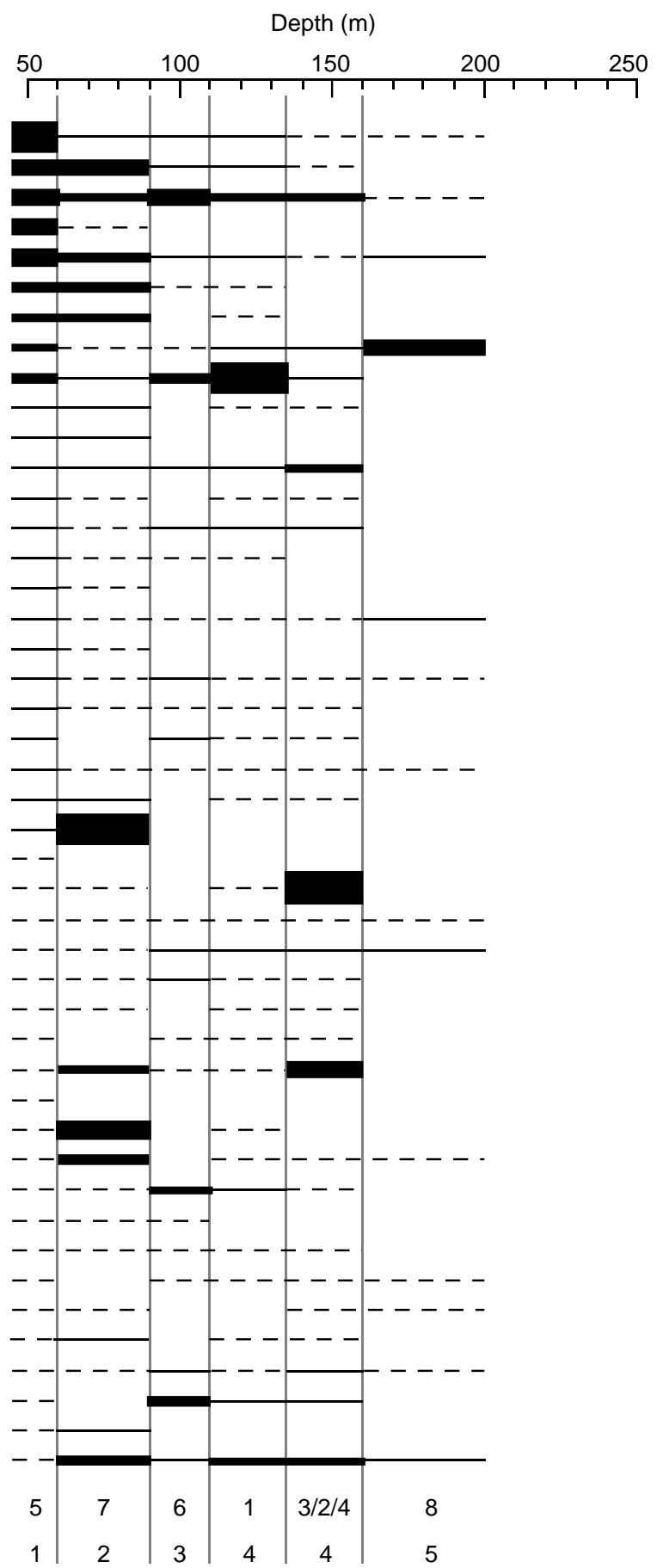

Figure 13. Depth ranges of lower to middle Eocene benthic foraminiferal species on the New Jersey Coastal Plain. 


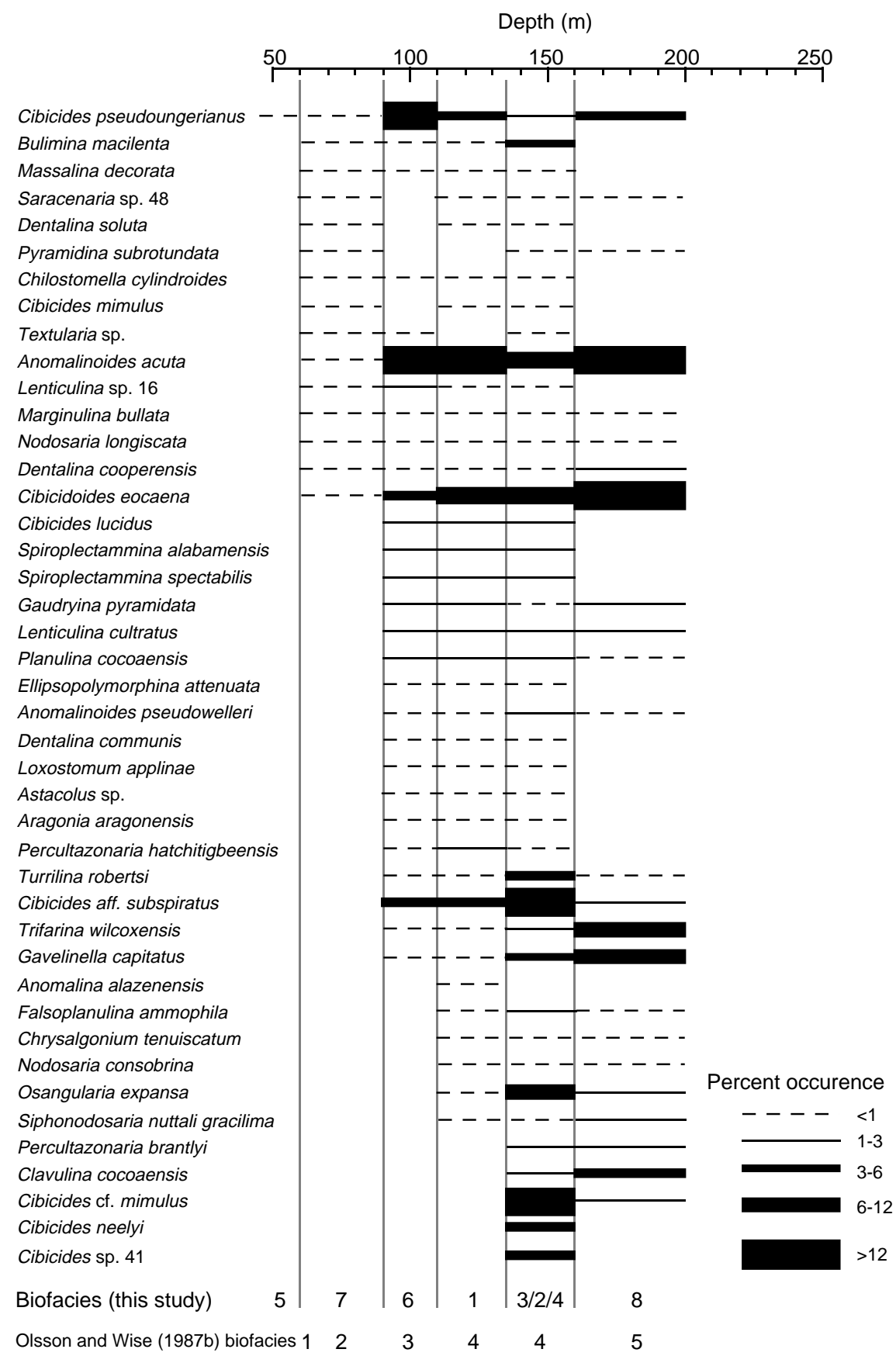

Figure 13 (continued). 


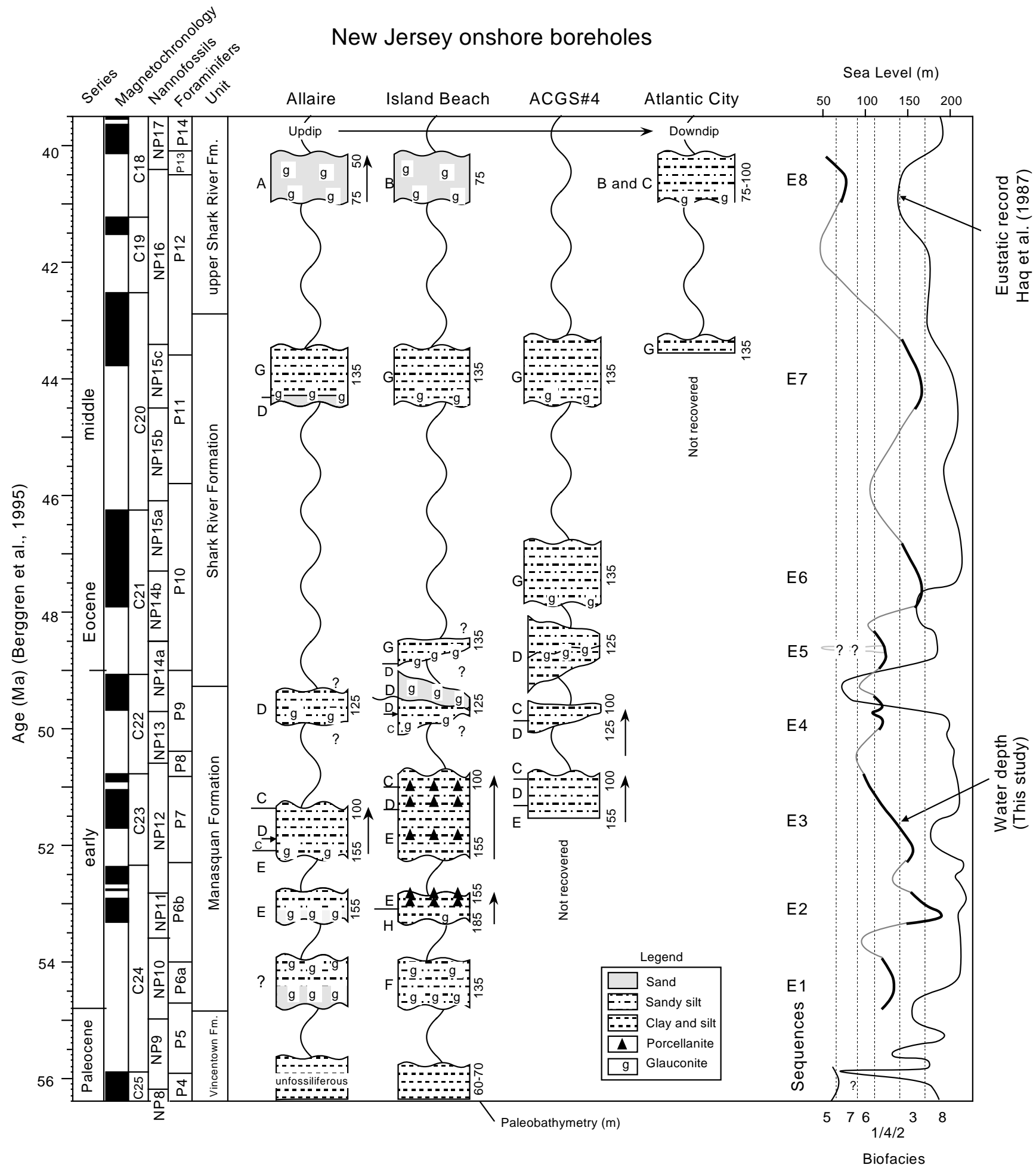

Figure 14. Distribution of sediments from the New Jersey Coastal Plain. Time is shown as a function of time plotted against the inferred water-depth curve for New Jersey and the eustatic record of Haq et al. (1987). All ages are calibrated to the time scale of Berggren et al. (1995). The water-depth curve is stippled where data are lacking. Wavy lines indicate unconformities. E1 to E8 indicate Eocene sequences. Letters A through $\mathrm{H}$ indicate benthic Biofacies A through $\mathrm{H}$ defined in text. Paleodepth estimate for the Vincentown Formation from Liu et al. (Chapter 10, this volume). Arrows indicate depth gradient within sequences. 